\title{
Real-world treatment patterns and outcomes in small-cell lung cancer: a systematic literature review
}

\author{
Sukhvinder Johal ${ }^{1}$, Robert Hettle ${ }^{1}$, Joe Carroll ${ }^{2}$, Peter Maguire ${ }^{2}$, Tammy Wynne ${ }^{2}$ \\ ${ }^{1}$ AstraZeneca, Cambridge, UK; ${ }^{2}$ Wickenstones, Oxfordshire, UK \\ Contributions: (I) Conception and design: All authors; (II) Administrative support: J Carroll, P Maguire, T Wynne; (III) Provision of study materials \\ or patients: All authors; (IV) Collection and assembly of data: J Carroll, P Maguire, T Wynne; (V) Data analysis and interpretation: All authors; (VI) \\ Manuscript writing: All authors; (VII) Final approval of manuscript: All authors. \\ Correspondence to: Peter Maguire. 127 Olympic Avenue, Milton Park, Abingdon, Oxfordshire OX14 4SA, UK. Email: peter@wickenstones.com.
}

\begin{abstract}
Background: Small-cell lung cancer (SCLC) accounts for $12-15 \%$ of lung cancers and is associated with poor survival outcomes and high symptom burden. This study employed a broad, systematic search strategy and timeframe to identify evidence on real-world treatment patterns and outcomes for SCLC outside the USA, including understanding sub-populations such as extensive-stage (ES) or limited-stage (LS) disease.

Methods: Databases (MEDLINE, Embase, and EBM reviews) were searched for journal articles published in the English language between 1 January 2000-1 March 2020 and supplemented by hand searching of conference abstracts and posters presented at conferences between 1 January 2016-1 March 2020 reporting real-world treatment outcomes in patients with SCLC. A targeted clinical guideline review was also completed. Results: One-hundred studies provided quantitative data; 57 were available as full-text articles, whilst the remaining 43 were presented as abstracts or posters. The majority (80 studies, $80 \%$ ) of included studies reported treatment in the first-line setting, where platinum-based chemotherapy and chemoradiotherapy was the most commonly used treatment strategy, in line with current treatment guidelines in SCLC. Firstline treatments were found to have a high response rate; however, most patients relapsed early. No studies reported treatment or outcomes with immune-oncology therapies. Second-line treatment options were very limited, and primarily consisted of either re-treatment with first-line regimen or topotecan, but the prognosis for these patients remained poor. Outcomes were particularly poor amongst those with ES or relapsed disease $v s$. LS disease.

Conclusions: SCLC treatment patterns and short survival outcomes have remained constant over the previous 20 years. Due to the search timeframe, none of the studies identified reported on the impact of recently approved immune-oncology therapies in SCLC. Further data is needed on the impact of immunotherapies on treatment patterns and real-world outcomes in SCLC.
\end{abstract}

Keywords: Small-cell lung cancer (SCLC); systematic literature review; treatment patterns; treatment outcomes; survival; real-world

Submitted Oct 07, 2020. Accepted for publication Mar 25, 2021.

doi: $10.21037 /$ jtd-20-3034

View this article at: http://dx.doi.org/10.21037/jtd-20-3034

\section{Introduction}

Approximately $10-15 \%$ of lung cancer cases are classified as small-cell lung cancer (SCLC), which is associated with an extremely poor rate of survival of $6.9 \%$ at 5 years from the point of diagnosis for the vast majority of patients (1). SCLC has a complex molecular pathogenesis with a high mutational burden and genomic instability, with SCLC patients commonly experiencing metastases, including brain metastases, which are present in around $10 \%$ of patients at diagnosis and developing in about $40-50 \%$ as the disease progresses (2).

Staging of SCLC has traditionally been performed 
according to the Veterans Administration Lung Study Group (VALSG) two-stage method, which classifies SCLC into limited-stage (LS) disease (confined to the ipsilateral hemithorax and all known disease can be encompassed within a single radiation port) and extended-stage (ES) disease (disease in the contralateral hemithorax and distant metastases) disease (3). Recent staging projects have shown that tumour node metastasis (TNM) staging of SCLC (LS defined as absence of distant metastatic disease), combined with the VALSG method, provides more accurate prognoses and treatment options $(4,5)$.

In comparison to non-SCLC, there have been limited therapeutic advances in the management of SCLC over the past 30 years. Topotecan was approved for the treatment of relapsed SCLC by the Food and Drug Administration (FDA) and European Medicines Agency (EMA) in 2007 and 2009, respectively. More recently, atezolizumab and durvalumab, immune checkpoint inhibitors, were approved in USA for firstline treatment in ES SCLC patients when used with etoposide plus either cisplatin or carboplatin $(6,7)$. Consequently, given the lack of therapeutic developments, long-standing chemotherapies and radiotherapies are extensively used in the treatment of SCLC with limited success; median survival for patients with LS disease is currently $15-20$ months, with $20-40 \%$ surviving to 2 years, and for those with ES disease, median survival is $8-13$ months with $5 \%$ surviving to 2 years (8). Reports of prophylactic cranial irradiation (PCI) have shown a decrease in the incidence of brain metastases and some have shown an improvement in overall survival (OS) (9). Other notable agents in late-stage development include pembrolizumab, under evaluation in both first-line and relapsed SCLC (10-12).

A recent study by Povsic et al. assessed the real-world comparative effectiveness and tolerability of a defined set of SCLC treatments (immune-therapy, single-agent or combination chemotherapy, or radiotherapy) published between 2006-2018 (13). OS was found to be poor in SCLC and no treatment option included was found to be clearly superior. Furthermore, real-world treatment effectiveness and tolerability data were found to be fragmented and inconsistently reported, with available publications primarily of poor quality and lacking statistical analyses.

To our knowledge, no systematic exploration of the full SCLC treatment landscape has been previously published; with ongoing clinical research into novel options, there is value in mapping this landscape to understand the state of treatment options in this indication. Questions remain in the literature regarding the breadth of the SCLC treatment landscape, differential treatment patterns and outcomes for SCLC sub-populations, and the degree to which practices reflect clinical guidelines. In addition, previous reviews have largely focused on real-world treatment patterns from database registries in the USA, and hence there is a need to more closely review evidence from outside the USA.

In this review, we aimed to employ a broad, systematic search strategy and timeframe to explore treatment patterns and outcomes for SCLC in the real world outside the USA, including understanding sub-populations by stage (LS $v s$. ES), line of therapy, and prophylaxis for brain metastases. A targeted search was carried out to identify clinical guidelines globally (including the USA) to contextualise the results of the real-world treatment review. Real-world studies from the USA were excluded to pragmatically restrict an already broad search strategy.

We present the following article in accordance with the PRISMA (Preferred Reporting Items for Systematic Reviews and Meta-Analyses) reporting checklist (available at http://dx.doi.org/10.21037/jtd-20-3034).

\section{Methods}

\section{Systematic literature review}

A systematic review was conducted to identify publications reporting on real-world treatment patterns and outcomes in patients with SCLC. This review is reported in accordance with the PRISMA statement (14).

\section{Eligibility criteria}

The review included all observational studies published in English between January 2000 and March 2020 which provided quantitative data on the classification, clinical management, rates of treatment for adult patient outcomes in SCLC outside the USA, regardless of stage or type of disease. Clinical trials were excluded as they are based on treatment within a controlled setting and may not reflect current clinical practice. Furthermore, case studies and opinion pieces were also excluded from this review as they provided limited quantitative data on treatment patterns or treatment outcomes. Samples of general lung cancer patients were included if they reported on subgroup data specific to the SCLC population. Further information on study eligibility in terms of population, intervention(s), comparator(s), outcomes and study design (PICOS) is provided in Table 1. 
Table 1 PICOS inclusion and exclusion criteria

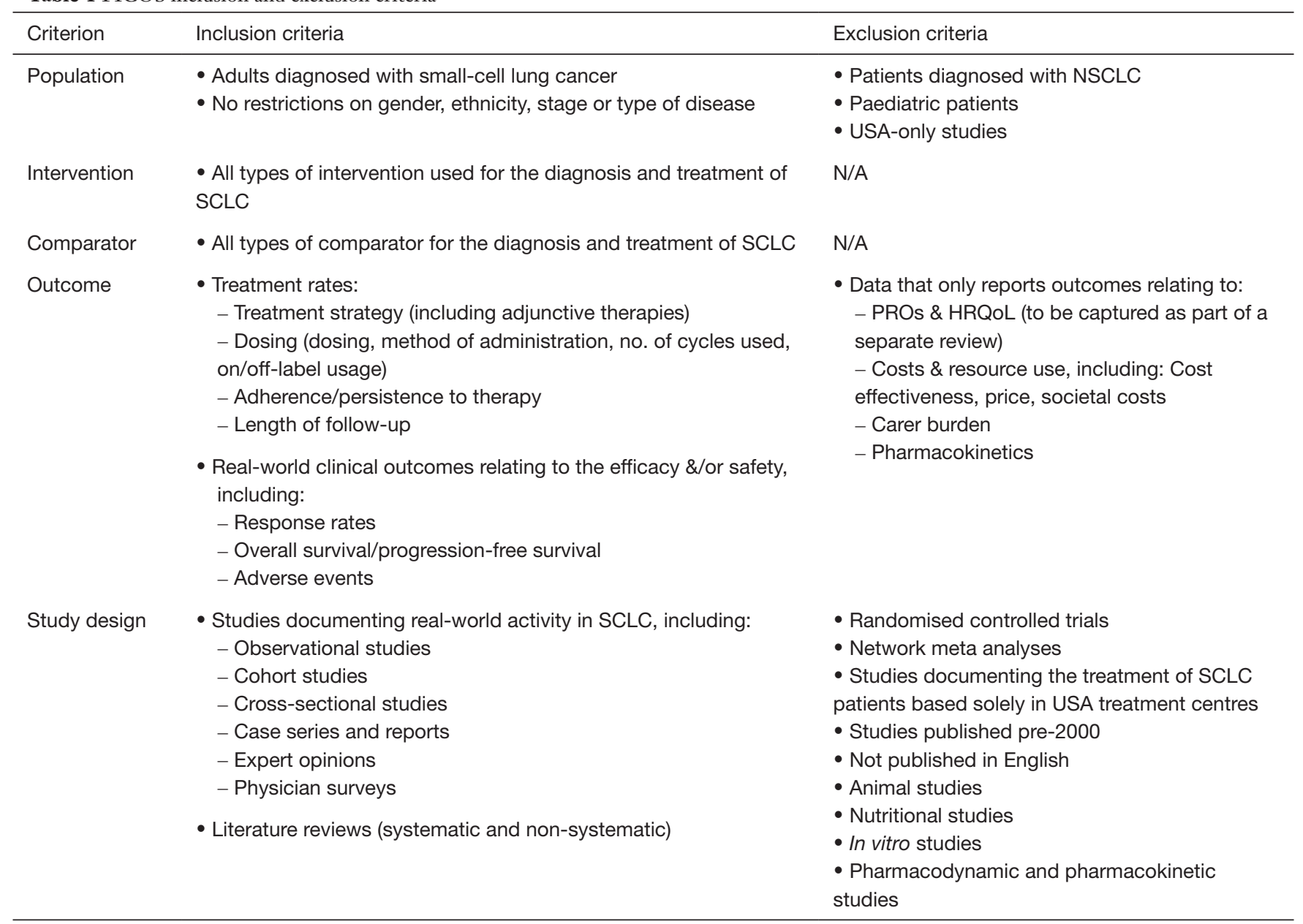

SCLC, small-cell lung cancer; PRO, patient-reported outcome; HRQoL, health-related quality of life.

\section{Search strategy and information sources}

Electronic databases (MEDLINE, Embase and EBM reviews) were searched systematically in December 2018, with searches reran in March 2020 to account for any newly published data (i.e., between January 2019 and March 2020). The search terms used in the Embase and MEDLINE databases are provided in Table S1 of the supplementary material. Notably, we did not pre-define the treatments of interest, but captured all therapies in the population of interest. Data on treatment patterns and/or outcomes not yet available in full manuscript form were identified through grey literature searches of posters and abstracts published at the following conferences between January 2016 and March 2020; ASCO, ESMO, ECC, WCLC, ALCC and JLCC. Furthermore, a bibliography review of all included studies was performed to capture any additional publications not identified throughout the core searches.

\section{Data collection and extraction}

All records identified in the searches were screened independently by two reviewers against eligibility criteria for full-text review with discrepancies resolved with the aid of a third independent reviewer. Data extraction from full texts was performed independently in duplicate. Information on study design, patient characteristics, outcomes, and conclusions was extracted from each full text or congress abstract. If congress posters were retrievable, data were extracted from the poster, if not, data were extracted from the abstract.

\section{Data analysis}

A qualitative synthesis of the evidence was completed and is described in a narrative summary in the results. Quantitative analyses or meta-analyses were not undertaken in this review. 


\section{Risk of bias assessment}

As no quantitative synthesis was performed, and due to the limited methodological information reported in the included congress abstracts, no quality assessment checklist was deemed relevant to the range of outcomes reported.

\section{Protocol}

The study protocol for this review was not registered.

\section{Targeted search for guidelines}

Supplemental targeted online searches of European and North American professional society and guideline agency websites were conducted in December 2018 and March 2020. The searches sought to identify any clinical guidelines or consensus statements on the diagnosis, staging or treatment of SCLC.

\section{Results}

\section{Study selection}

Across both the December 2018 and March 2020 searches of bibliographic databases, conference publications and other web-based resources, 6,465 unique records were identified. After the screening process, 272 records were reviewed as full texts or congress abstracts. One-hundred records, all reporting observational studies, were included (Figure 1).

\section{Study characteristics}

Table 2 summarises the characteristics of the 100 observational studies, of which 57 were full text articles and 43 congress abstracts or posters (full results available in Table S2 of the supplementary material). All but one record were of unique retrospective studies (99\%), with one prospective tracking study (1\%). Studies had a broad geographic spread: coming from Europe (25\%), Asia-Pacific (56\%), North America and South America (10\%), and the Middle East, Turkey, and North Africa (7\%). The majority of studies were published in the last twelve years (97\%), and three (3\%) studies before 2008 .

\section{Patient characteristics}

Most studies reported on patients undergoing first-line treatments (80\%), with 17 studies (17\%) following patients in second and subsequent lines of therapy, and, a further 3 studies (3\%) assessing treatment of secondary brain metastases in SCLC patients (Table 3). Eighteen studies reported treatment of patients with LS, 14 of patients with ES, and the remaining 30 of patients at a variety of stages. A further 16 and 2 studies reported on PCI and maintenance therapies following induction chemotherapy in first-line SCLC, respectively. Twenty-six studies reported disease functioning scales, most commonly the ECOG performance status (15-30), or the Karnofsky performance status (31-36).

Demographics of patients from the quantitative studies matched the SCLC patient profile described in the literature (37), whereby patients are likely to be male and over 50 years of age. In the 62 studies reporting age, the average patient age was over 50 years (medians between 55 and 75 ), and in $83 \%$ of studies reporting age, over 60 years. Males comprised a larger proportion within study cohorts in all but one study (38). Twenty-four studies reported the smoking status or smoking history of their cohorts. In most studies $(n=23)$ that reported smoking status, current smokers and former smokers comprised the majority of the cohort. Twenty-seven studies reported rates of brain metastases in their cohort prior to treatment, but this varied between study, ranging from $0 \%$ (39) to $64 \%$ (40), with the typical cohort comprising $10-30 \%$ of patients with brain metastases $(n=18)$.

\section{Treatment patterns: first-line}

\section{Limited stage}

Fifty-three records reporting on first-line treatment included LS SCLC patient cohorts: with 46 studies reporting use of chemotherapy, either alone or in combination with thoracic radiotherapy. In 36 studies, a majority of patients received a chemotherapy regimen of etoposide, combined with platinum-based treatment, most typically for 4-6 cycles. The remaining patients in these studies received either PCDE (cisplatin, cyclophosphamide, doxorubicin, etoposide), PEI (cisplatin, etoposide, ifosfamide), CAV (cyclophosphamide, doxorubicin, vincristine), cyclophosphamide or amrubicin regimens. A slight preference of cisplatin was found over carboplatin in studies which included patients who had received a platinum-based regimen (15,41-47). Surgical resection followed by chemotherapy or chemoradiotherapy was used in 4 studies, in which all patients had either stage I or stage II disease under the TNM classification system. 


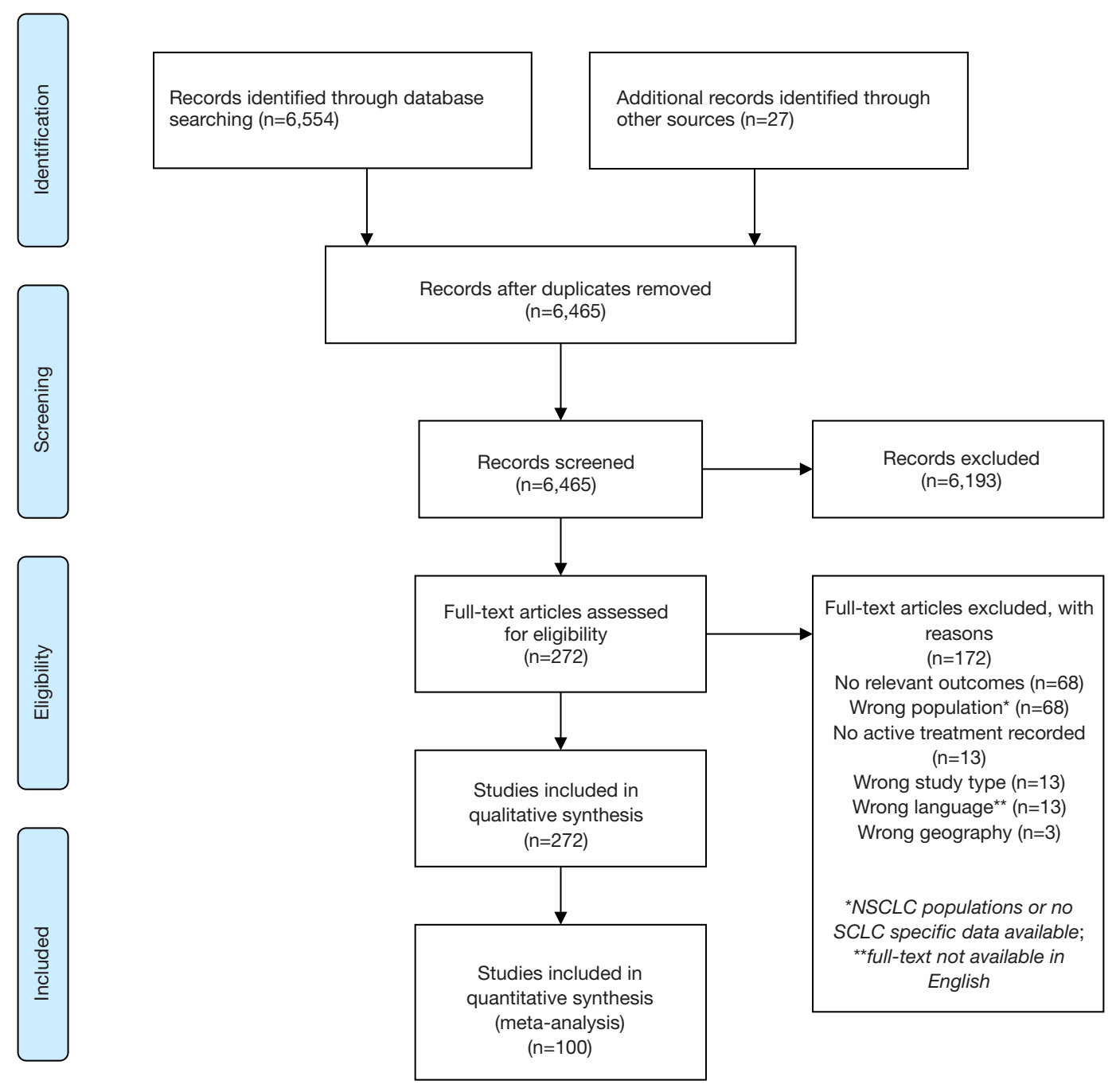

Figure 1 PRISMA flow diagram.

\section{Extensive stage}

Eleven studies were identified specific to ES patients in the first-line setting $(18,31,32,36,48-55)$. No studies reported use of immunotherapy agents. Instead, all reported patients were treated with either chemotherapy or chemoradiotherapy. Of those that provided the exact chemotherapy regimen, all reported a platinum-based therapy combined with etoposide. Most studies did not report a preference for either cisplatin or carboplatin. However, of the 3 studies which reported a majority of patients receiving cisplatin, 2 were from China and 1 from Thailand $(32,36,52,55)$. Chemoradiotherapy was reported in five of twelve studies specific to first line in ES SCLC $(31,32,36,48,51)$. The proportion of the radiotherapy uptake in those studies ranged from $44.5-61 \%(31,48)$.

\section{PCI}

Thirty-four studies reported patients being treated with PCI, 16 in which all patients were treated with PCI as the main intervention in the study. PCI was used less frequently among ES patients [range $1.6 \%-12.4 \%$ of patients, 4 studies $(31,32,35,51)$ ] compared with LS [range, 33-61.5\% of patients, 10 studies $(16,29,41,42,44,45,56-59)]$. Uptake of PCI amongst mixed intervention cohorts ranged between $1.6 \%$ and $61.5 \%(36,60)$.

\section{Treatment patterns: relapsed/refractory disease}

Seventeen studies $(21,23,24,28,40,61-70)$ reported on the treatment of SCLC patients beyond first-line treatment. Patients were either retreated with their first- 
Table 2 Characteristics (study and patient) of the included studies

\begin{tabular}{|c|c|}
\hline Characteristics of records & $\mathrm{N}(\%)$ \\
\hline No. of studies included in final analysis & 100 \\
\hline \multicolumn{2}{|l|}{ Publication type } \\
\hline Full journal articles & $57(57 \%)$ \\
\hline Congress abstracts & $43(43 \%)$ \\
\hline \multicolumn{2}{|l|}{ Year of publication } \\
\hline 2013-present & $70(70 \%)$ \\
\hline 2008-2013 & $27(27 \%)$ \\
\hline Pre-2008 & $3(3 \%)$ \\
\hline \multicolumn{2}{|l|}{ Type of study } \\
\hline Retrospective & $100(100 \%)$ \\
\hline \multicolumn{2}{|l|}{ Country/continent } \\
\hline International & $2(2 \%)$ \\
\hline Europe & $25(25 \%)$ \\
\hline Denmark & 2 \\
\hline France & 2 \\
\hline Germany & 5 \\
\hline Netherlands & 1 \\
\hline Poland & 2 \\
\hline Portugal & 1 \\
\hline Serbia & 1 \\
\hline Slovakia & 1 \\
\hline Slovenia & 2 \\
\hline Spain & 4 \\
\hline UK & 4 \\
\hline Asia & $56(56 \%)$ \\
\hline Australia & 1 \\
\hline China & 24 \\
\hline India & 1 \\
\hline Japan & 24 \\
\hline Korea & 2 \\
\hline New Zealand & 1 \\
\hline Singapore & 1 \\
\hline Thailand & 2 \\
\hline
\end{tabular}

Table 2 (continued)
Table 2 (continued)

\begin{tabular}{lc}
\hline Characteristics of records & $\mathrm{N}(\%)$ \\
\hline META & $7(7 \%)$ \\
Egypt & 1 \\
Israel & 1 \\
Turkey & 4 \\
Tunisia & 1 \\
America & $10(10 \%)$ \\
Canada & 8 \\
Brazil & 2 \\
Stage of disease/intervention* & \\
LS-SCLC (surgery) & $4(4 \%)$ \\
LS-SCLC (CT/CRT) & $14(14 \%)$ \\
ES-SCLC (CT/CRT) & $14(14 \%)$ \\
All ${ }^{\text {st }}$ line patients (LS-SCLC and ES-SCLC) & $28(28 \%)$ \\
PCl & $16(16 \%)$ \\
Treatment of secondary brain metastases & $3(3 \%)$ \\
Maintenance therapy & $3(3 \%)$ \\
Relapse or refractory disease & $17(17 \%)$ \\
\hline Not all studis are mutually exclusive with som & \\
\hline
\end{tabular}

*Not all studies are mutually exclusive with some reporting treatment patterns or outcomes in multiple SCLC populations. CT, chemotherapy; CRT, chemoradiotherapy; ES, extensive stage; LS, limited stage; META, Middle East, Turkey and Africa; $\mathrm{PCl}$, prophylactic cranial irradiation; SCLC, small cell lung cancer.

line platinum chemotherapy regimen, a topoisomerase inhibitor (either irinotecan, topotecan, or amrubicin) [11 studies, $(21,24,29,61-67,71,72)$ ], or paclitaxel [6 studies $(23,28,65,73-75)]$.

A single study included LS SCLC patients in second and subsequent lines of treatment (40). Fourteen patients in the Aktas et al. study were treated sequentially with irinotecan followed by topotecan while 11 patients received topotecan followed by irinotecan.

\section{Treatment outcomes}

\section{Limited stage}

Patients who underwent surgery had comparatively high 
Table 3 Clinical guidelines providing recommendations for the diagnosis, staging or treatment of small cell lung cancer

\begin{tabular}{|c|c|c|c|c|c|}
\hline Agency & Title of guideline & Jurisdiction & $\begin{array}{c}\text { Year of } \\
\text { publication }\end{array}$ & \multicolumn{2}{|c|}{ Guideline coverage } \\
\hline ESMO & $\begin{array}{l}\text { SCLC: ESMO Clinical Practice Guidelines } \\
\text { for diagnosis, treatment and follow-up } \\
\text { (Fruh et al., 2013, Jett et al., 2013) }\end{array}$ & Europe & 2013 & $\checkmark$ & $\checkmark$ \\
\hline ACCP & $\begin{array}{l}\text { Diagnosis and Management of Lung } \\
\text { Cancer, 3rd ed: ACCP Evidence-Based } \\
\text { Clinical Practice Guidelines (Jett et al., } \\
\text { 2013) }\end{array}$ & USA & 2013 & $\checkmark$ & \\
\hline ASCO & $\begin{array}{l}\text { Treatment of Small-Cell Lung Cancer: } \\
\text { ASCO Endorsement of the ACCP Guide- } \\
\text { line (Rudin et al., 2016) }\end{array}$ & USA & 2015 & $\checkmark$ & \\
\hline BTS & $\begin{array}{l}\text { Guidelines on the Radical Management } \\
\text { of Patients with Lung Cancer (Lim et al., } \\
\text { 2010) }\end{array}$ & UK & 2010 & $\checkmark$ & \\
\hline NICE & $\begin{array}{l}\text { Lung cancer: diagnosis and management } \\
\text { (Baldwin et al., 2011) }\end{array}$ & $\begin{array}{c}\text { UK } \\
\text { (England \& Wales) }\end{array}$ & 2011 & $\checkmark$ & $\checkmark$ \\
\hline SIGN & $\begin{array}{l}\text { SIGN 137: Management of Lung Cancer } \\
\text { [(SIGN), 2014] }\end{array}$ & Scotland & 2014 & $\checkmark$ & $\checkmark$ \\
\hline SEOM & $\begin{array}{l}\text { SEOM clinical guidelines for the treatment } \\
\text { of small-cell lung cancer (Domine Gomez } \\
\text { et al., 2013) }\end{array}$ & Spain & 2013 & $\checkmark$ & \\
\hline Alberta Health Services & $\begin{array}{l}\text { Clinical Practice Guideline LU-007: } \\
\text { Small Cell Lung Cancer: Extensive Stage } \\
\text { (Services, 2012b) }\end{array}$ & Canada & 2012 & $x$ & $\checkmark$ \\
\hline Cancer Care Ontario & $\begin{array}{l}\text { Initial Management of Small Cell Lung } \\
\text { Cancer (Limited and Extensive Stage) and } \\
\text { the Role of Thoracic Radiotherapy and } \\
\text { First-Line Chemotherapy (Ontario, 2017) }\end{array}$ & Canada & 2017 & $\checkmark$ & $\checkmark$ \\
\hline Cancer Care Ontario & $\begin{array}{l}\text { Chemotherapy for Relapsed Small Cell } \\
\text { Lung Cancer (Ontario, 2013) }\end{array}$ & Canada & 2013 & $\checkmark$ & \\
\hline Cancer Care Ontario & $\begin{array}{l}\text { Prophylactic Cranial Irradiation in Small } \\
\text { Cell Lung Cancer (Ontario, 2003) }\end{array}$ & Canada & 2003 & $x$ & $\checkmark$ \\
\hline
\end{tabular}

$\checkmark$ =included in recommendations; $x=$ not included in recommendations. ACCP, American College of Chest Physicians; ASCO, American Society of Clinical Oncology, BTS=British Thoracic Society; ESMO, European Society for Medical Oncology, HSE=Health Service Executive; NCCN, National Comprehensive Cancer Network; NICE, National Institute for Health and Care Excellence; SCLC, small lung cell cancer; SEOM, Spanish Society for Medical Oncology; SIGN, Scottish Intercollegiate Network. 
OS averages, with median OS ranging between 20.4 and 89 months [6 studies (33,44,56,76-79); Figure 2A]; use of surgery was confined to a very small subset of patients with LS disease, which may explain the higher OS values.

In LS patients undergoing chemotherapy and chemoradiotherapy treatments [ 14 studies, $(15,29,41$ $45,47,55,57,60,68,69,80)]$, median OS rates ranged from between 13.9 and 41.1 months [Figure $2 B$, $(29,45,55,57,60,68,80)]$. Thoracic radiotherapy delivered concurrently with chemotherapy produced favourable OS rates compared with when delivered subsequently [median OS 29.7 vs. 22.6 months (80), Median OS 41.1 vs. 38.1 months (45), 5 yr OS $27.3 \%$ vs. $11.7 \%$ (44), respectively]. No study reported the OS of patients treated with radiotherapy alone. Some studies $(42,45,69)$ commented on the higher rates of toxicity amongst those patients administered with higher doses.

Sixteen studies $(20,34,35,38,39,55,56,70,81-88)$ reported LS patients undergoing PCI (Figure 2C). The impact of PCI in improving survival vs. patients who did not receive PCI was mixed, with some studies demonstrating an OS/progression-free survival (PFS) improvement [ 8 studies $(20,34,35,38,39,83,85,86)$ ], whilst others showing no improvement or a reduced OS [3 studies $(82,84,88)]$. However, all but one (88) studies that reported on the incidence of brain metastases found the addition of PCI led to a reduction in incidence [7 studies $(20,34,35,39,81,87,89)]$.

\section{Extensive stage}

In all studies reporting OS in ES SCLC patients receiving first-line treatment, median OS was below 2 years, with median OS ranging between 5.9-18 months [12 studies (18,31,32,36,48-55); Figure 2D]. Amongst those patients who received platinum-based chemotherapy alone in the first-line setting, median OS ranged from 9.3-13 months $(18,49,50,52-54)$. The median PFS in ES SCLC following first-line treatment [10 studies $(18,31,32,36,48-52,54)]$ was $5-10$ months. In the 2 nd and $3 \mathrm{rd}$ line settings [17 studies $(21,23,24,28,40,61-67,71-75)]$, both PFS and OS were considerably shorter (PFS 1.5-8.2 months; OS see Figure 2E).

\section{Clinical guidelines in SCLC}

The targeted search of electronic database and online sources identified 14 relevant clinical guidelines from 11 professional bodies which provided recommendations on the diagnosis, staging or treatment of SCLC (Table 2). In Canada, the regional based agencies for Alberta and Ontario published guidelines separately for the management of SCLC by stage of disease (LS \& ES) and line of therapy (1L, PCI, R/R), respectively.

Overall, there was a high degree of alignment between the published guidelines. In the first-line setting, all agencies recommended treatment with platinum-based chemotherapy plus etoposide for a period of 4-6 cycles in both LS and ES patients. In LS disease, guidelines indicate that treatment is aimed to be curative, with surgery and thoracic radiotherapy considered as treatments to be used alongside platinum chemotherapy. All published clinical guidelines identified in this review recommended the use of concurrent chemoradiotherapy (with or without prior surgical resection) for first-line LS patients. In ES disease, additional treatment beyond platinum chemotherapy was limited to radiotherapy, however, the recommendations within this patient population were mixed, with most guidelines providing no specific recommendation or confining use to sequential radiotherapy for the palliation of patient symptoms. PCI was recommended as an option for both LS and ES patients if they had managed to achieve stable disease following initial treatment and had a good performance score using a validated metric (for example, ECOG score).

Amongst patients who did not respond to therapy or experienced an early relapse, clinical guidance notes that prognosis is poor and often recommends palliative management focused upon reducing tumour size-this is commonly recommended through best supportive care or clinical trials. In the case of a treatment-free interval of 3-6 months, guidelines recommend the use of topotecan or re-treatment with the patient's first-line platinum chemotherapy regimen.

\section{Discussion}

\section{Treatment patterns}

This study employed a broad, systematic approach to exploring treatment patterns and outcomes for SCLC in the real world, with a focus on understanding subpopulations by stage, line of therapy and PCI use. Clinical practice appears to be highly aligned with existing treatment guidelines in SCLC, brought about by the lack of therapeutic developments over the time frames of the included studies, driving consensus amongst the clinical 
A

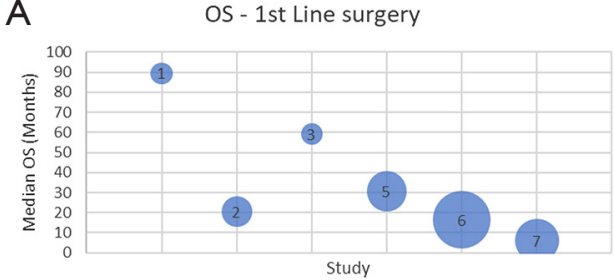

C

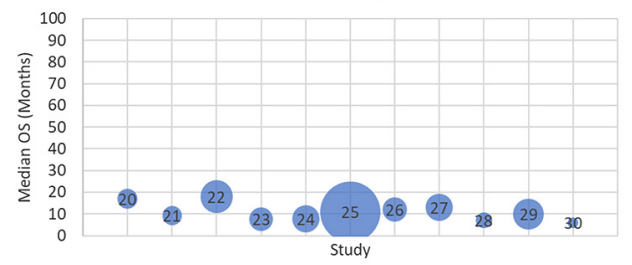

E

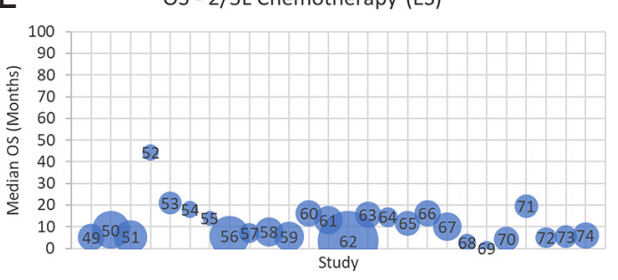

Ploenes et al. (surgery+neoadjuvant)

Ploenes et al. (surgery)

Ogawa et al.

Zhang et al. (surgical)

Zhang et al. (non-surgical)

Bagshaw et al. (surgery)

Dong et al. (concurrent chemoradiotherapy)

Dong et al. (sequential chemoradiotherapy)

Hermes et al. (1-4 cycles)

Hermes et al. (5-6 cycles)

Aynaci et al.

Matsuura et al. (45 GY)

Matsuura et al. (54 GY)

Chen et al. (concurrent chemoradiotherapy)

Chen et al. (non-concurrent chemoradtiotherapy)

$\mathrm{O}$ Hara et al. (concurrent chemoradiotherapy)

O Hara et al. (sequential chemoradiotherapy)

Sukauichai et al.

Zhu et al. (chemoradiotherapy)

Zhu et al. (chemotherapy)

Luan et al.

Mellemgaard et al. (Etoposide oral)

Mellemgaard et al. (Etoposide IV)

Sallam et al. (4 cycles)

Sallam et al. ( $>4$ cycles)

Sedef et al.

Shirasawa et al. (with interstitial pneumonia)

Shirasawa et al. (without interstitial pneumonia)

Sukauichai et al.

Ramlov et al. (Limited Stage)

Ramlov et al. (Extensive Stage)
B

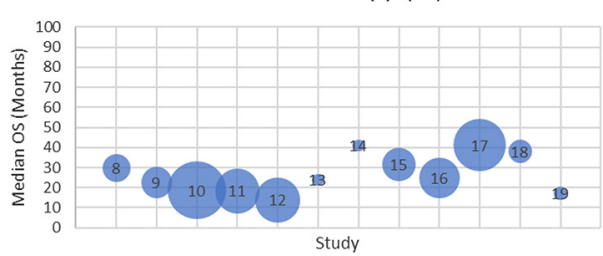

D

OS - PCl

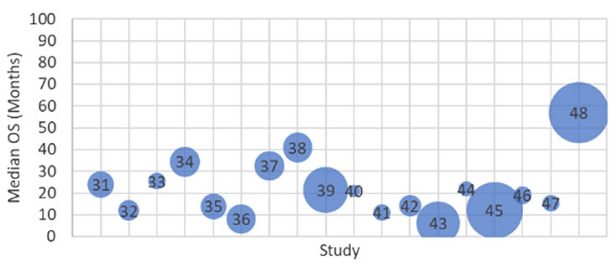

Ozawa et al. (PCl)

Ozawa et al. (No PCl)

Bang et al. (PCl)

Bang et al. (No PCl)

Qui et al. (Early PCl)

Qui et al. (Late PCl)

Qui et al. (No PCl)

Matutino et al. (PCl)

Matutino et al. (No PCl)

Srivastava et al. (PCl)

Srivastava et al. (No PCl)

Stanic et al. (PCl)

Stanic et al. (No PCl)

Boskovic et al. (PCl)

Boskovic et al. (No PCl)

Liu et al. (Limited Stage)

Asai et al.

Inomata et al.

Morise et al.

Murakami et al. (Re-challenge)

Murakami et al. (AMR)

Aktas et al. (IRI/TOP)

Aktas et al. (TOP/IRI)

Granados et al.

Itotani et al.

Minemura et al. (Sensitive relapse)

Minemura et al. (Refractory relapse)

Zhang et al. (PE+IRO)

Zhang et al. (TOP)

von Eiff et al.

Shufei et al. (IRO+NED)

Shufei et al. (IRO+P)

Sone et al.

Wang et al. (IRO+PE)

Wang et al. (TOP)

Saijo et al. (Relapsed)

Moharana et al. (Recurrent)

Sugiyama et al.

Zhao et al. (IRI)

Zhao et al. (TOP)

Zhao et al. (PTX)

Zhao et al. (DTX)

Figure 2 Median rates of overall survival from each study stratified by study cohort. (A) Median overall survival in studies assessing firstline surgical interventions in small-cell lung cancer*. (B) Median overall survival in studies assessing first-line chemotherapy interventions in extensive stage small-cell lung cancer*. (C) Median overall survival in studies assessing first-line chemotherapy interventions in extensive stage small-cell lung cancer*. (D) Median overall survival in studies assessing prophylactic cranial irradiation in small-cell lung cancer*. (E) Median overall survival in studies assessing second-and third-line chemotherapy interventions in extensive stage small-cell lung cancer*. *The size of each bubble is representative of the study's sample size. 
community. None of the included studies captured realworld data for the use or outcomes of durvalumab or atezolizumab, which are expected to become the future standards of care for first-line ES-SCLC.

Among first-line LS patients, chemoradiotherapy consisting of once or twice daily thoracic radiotherapy with etoposide plus either cisplatin or carboplatin is the standard of care treatment. Concurrent chemoradiotherapy has been shown in earlier studies to provide improved outcomes relative to sequential treatment $(90,91)$. Thus, guidelines and current clinical practice show that sequential chemoradiotherapy is limited to a small subset of LS patients who are unable to tolerate an intensive combined regimen (for example, elderly patients or those with a poorer performance status). We identified limited uptake of surgery within the published data, which is most likely explained by SCLC being an aggressive disease which usually presents in advanced forms at the point of diagnosis, thus limiting the potential pool of patients who could be eligible for resection.

In ES patients, the progression of the disease limits treatment options. As a result, the standard of care is platinum-based chemotherapy with etoposide, which was the reported therapeutic strategy in $>80 \%$ of first-line ES patients. There was a slight preference for the use of cisplatin over carboplatin, which produces better survival outcomes but is associated with a more unfavourable adverse event profile (92). This suggests that mostly younger, fitter patients were being enrolled onto active treatment, in line with the clinical guidelines. Thoracic radiotherapy has limited uptake when compared to the LS population, with almost all ES-patients who received chemoradiotherapy receiving it sequentially, and, usually only for the palliation of symptoms. Due to most real-world studies containing both ES SCLC and LS SCLC patients, and, not always providing subgroup data, it remains difficult to accurately estimate the scale of uptake for chemoradiotherapy in ES SCLC. However, a high volume of ES SCLC specific studies only included patients who had received chemotherapy, suggesting chemoradiotherapy has a limited role in ES disease.

The published literature reports a high response rate to first-line treatment (approx. 70\%), however, patient relapse is frequent and rapid (93). Despite a high proportion of patients requiring $2^{\text {nd }}$ line (and $3^{\text {rd }}$ line treatment), there was a limited number of studies which reported on treatment patterns and/or outcomes for this population. This could suggest that most patients who relapse or are refractory to first-line treatment have a poor medical prognosis and thus may not be considered fit enough to undergo active treatment (94). Among the published studies in the relapsed setting, we found a consistency between the guidelines and current practice, with most patients receiving either a topoisomerase inhibitor (irinotecan or topotecan) or retreatment with their previous first-line chemotherapy regimen. In older patients, usually defined as those over 70 years of age, we found a preference for enrolment onto amrubicin, which was not always explicitly recommended in the published treatment guidelines.

\section{Treatment outcomes}

The review confirmed the limitations of current therapeutic approaches in SCLC for all but small subset of patients. In LS disease, surgical resection followed by adjuvant chemotherapy provided the best outcomes, with high rates of survival reported at 5 years for all but one study. Concurrent chemoradiotherapy was also an effective option; with studies reporting a high degree of patients surviving beyond 2 years. However, these treatment options are only considered appropriate for the estimated $30 \%$ of SCLC patients who present with LS disease at diagnosis. In the remaining $70 \%$ of SCLC patients with ES disease, treatment outcomes are notably poorer. Platinum-based chemotherapy delivers high initial response rates, however, most patients relapse early, contributing to a median survival which rarely exceeded 12 months for the studies we identified in this review. Second-line treatment options primarily consist of either re-treatment with a patients first-line regimen or topotecan, but the prognosis for these patients remains poor with most studies reporting a median OS of between 4 and 8 months.

The findings from our review with respect to treatment outcomes were aligned with a previous, more targeted, review of effectiveness of individual therapies (13). This was also confirmed by a systematic review of randomised controlled trials by Cope et al. for a range of different treatments across all stages of SCLC (95). Our results further highlight that poor outcomes are particularly evident amongst those with ES vs. LS disease, including both those who undergo surgical resection or receive chemoradiotherapy. Second- and third-line treatment options were seen to have limited effect in ES patients, contributing to limited uptake of active treatment and poor survival outcomes in this population. There is a clear unmet need for new treatment options which could delay the time 
to relapse in first-line patients or improve survival outcomes for those patients in relapsed and remission settings. In recent clinical studies, both atezolizumab and durvalumab have demonstrated improvements in median OS of 2.0- and 2.7-month $v s$. platinum chemotherapy alone in first-line ES-SCLC patients, respectively. The availability of these new options could pave the way for a higher durability of response, and, in turn, survival $(6,7)$.

\section{PCI}

We examined studies exploring PCI as a sub-set of interest. Because the blood-brain barrier restricts the penetration of most chemotherapeutic agents into the brain, leaving the brain a susceptible site for relapse, PCI is considered in patients who have responded to therapy; however, because most ES patients are in a poor medical state, PCI is often not considered appropriate. Based on this review, uptake of PCI in this population is approximately 10 $20 \%$. Furthermore, the clinical benefit of PCI is unclear, particularly in the ES population. Most studies of firstline ES disease explored the efficacy of platinum-based chemotherapy, and although all studies included a cohort of patients who subsequently received PCI, no subgroup analyses of these patients were performed. Therefore, only a limited number of real-world studies which specifically examined the impact of adjuvant PCI could be used. These studies demonstrated that PCI resulted in significant reductions in the incidence of brain metastases compared with patients who did not undergo PCI. However, a reduction in brain metastases did not necessarily translate to a survival benefit, with studies presenting varied results. This finding is aligned with a recent systematic review of PCI, which concluded that, although data appeared to show PCI improved survival, this may be confounded by issues such as whether brain imaging had been used to confirm presence of brain metastases (96).

\section{Gaps in the literature}

Several data gaps were identified in this review. One area with a paucity of data was in the second-line treatment of SCLC patients. Those studies that did have a cohort of second-line patients show the role of second-line treatments is usually palliative with an emphasis on extending life and reducing symptom burden. In addition, there were limited studies focussed on patients with ES and relapsed disease. Furthermore, those studies that did report in these subgroups were typically small single-centre studies, from disparate geographic settings.

\section{Study limitations}

This study had some methodological limitations. Firstly, our analysis of current management in the USA was limited to guidelines only; the primary reason for this was to pragmatically restrict an already extremely broad search (with the USA anticipated to have a high volume of literature). However, our review found a high degree of alignment between treatment guidelines, irrespective of country. Furthermore, we found no differences in clinical practice between countries using real-world data. Therefore, we believe that current treatment in the USA will align to their respective guidelines. Secondly, only real-world data was identified from studies published in the literature and our search strategy did not involve specific database or registry searches. However, given the large volume of studies which were identified as congress abstracts, which included a number of small single-centre chart reviews or database analyses, we believe that most sources of data will have been captured in our review.

Thirdly, our analysis was strictly qualitative with no quantitative synthesis being performed. This was the aimgiven the amount of heterogeneity between studies, a quantitative analysis would have considerable uncertainty and necessitate a more restrictive search strategy. Finally, the review did not incorporate an assessment of study quality using a validated questionnaire or survey as our analysis was limited to a qualitative exploration of treatment patterns and outcomes and did not include any quantitative evidence syntheses. Furthermore, as a number of studies identified in this review were congress abstracts, they had limited information on study methods, meaning it would be difficult to complete any assessment of study quality using standard instruments.

\section{Conclusions}

To our knowledge, this is the broadest systematic search of real-world treatment patterns and outcomes in SCLC. SCLC has poor survival outcomes, particularly in patients with ES disease. Treatment practices are well-aligned to clinical guidelines, which partly reflects the limited options available to treat SCLC. Consequently, outcomes have not considerably improved during at least the last twenty years. Furthermore, although PCI is recommended by 
guidelines and has been shown to have clinical benefit, the impact on OS is questionable and it may be unsuitable for patients with poor performance status (such as those with ES disease). Although a wide variety of study designs were identified, there was a paucity of data in second and subsequent lines of therapy, and in ES disease patients specifically. This review highlights a need for more efficacious treatments to mitigate the burden of disease. There is also a need for longitudinal and patient-centred studies with treatment-specific results, to better explore the disease- and treatment-related burden on patients and to better understand the long-term survival rates of patients with SCLC. The impact of upcoming new standards of care, such as durvalumab and atezolizumab, also needs to be assessed as more data become available.

\section{Acknowledgments}

Funding: AstraZeneca funded the analysis and manuscript preparation. $\mathrm{RH}$ and $\mathrm{SJ}$ are current employees of AstraZeneca. JC, PM and TW are current employees of Wickenstones. Employees of the funding company (RH and SJ at AstraZeneca) were involved in the definition of the research question, the design of the search strategy, the analysis and presentation of results, the decision to publish this research, and had final approval of this manuscript. Wickenstones were commissioned by AstraZeneca to conduct and publish this research. Wickenstones paid the salaries of JC, PM, and TW.

\section{Footnote}

Reporting Checklist: The authors have completed the PRISMA reporting checklist. Available at http://dx.doi. org/10.21037/jtd-20-3034

Conflicts of Interest: All authors have completed the ICMJE uniform disclosure form (available at http://dx.doi. org/10.21037/jtd-20-3034). SJ and RH report grants from AstraZeneca plc, Cambridge, UK, during the conduct of the study. JC, PM and TW report grants from AstraZeneca plc, Cambridge, UK, grants from Wickenstones ltd, Oxfordshire, UK, during the conduct of the study; and grants from AstraZeneca, outside the submitted work.

Ethical Statement: The authors are accountable for all aspects of the work in ensuring that questions related to the accuracy or integrity of any part of the work are appropriately investigated and resolved.

Open Access Statement: This is an Open Access article distributed in accordance with the Creative Commons Attribution-NonCommercial-NoDerivs 4.0 International License (CC BY-NC-ND 4.0), which permits the noncommercial replication and distribution of the article with the strict proviso that no changes or edits are made and the original work is properly cited (including links to both the formal publication through the relevant DOI and the license). See: https://creativecommons.org/licenses/by-nc-nd/4.0/.

\section{References}

1. Oronsky B, Reid TR, Oronsky A, et al. What's New in SCLC? A Review. Neoplasia 2017;19:842-7.

2. Quan AL, Videtic GM, Suh JH. Brain metastases in small cell lung cancer. Oncology (Williston Park, NY) 2004;18:961-72; discussion 74, 79-80, 87.

3. Mountain CF. Revisions in the International System for Staging Lung Cancer. Chest 1997;111:1710-7.

4. Lim E, Baldwin D, Beckles M, et al. Guidelines on the radical management of patients with lung cancer. Thorax 2010;65 Suppl 3:iii1-27.

5. Giroux DJ, Rami-Porta R, Chansky K, et al. The IASLC Lung Cancer Staging Project: data elements for the prospective project. J Thorac Oncol 2009;4:679-83.

6. Paz-Ares L, Dvorkin M, Chen Y, et al. Durvalumab plus platinum-etoposide versus platinum-etoposide in firstline treatment of extensive-stage small-cell lung cancer (CASPIAN): a randomised, controlled, open-label, phase 3 trial. Lancet (London, England) 2019;394:1929-39.

7. Horn L, Mansfield AS, Szczesna A, et al. First-Line Atezolizumab plus Chemotherapy in Extensive-Stage Small-Cell Lung Cancer. N Engl J Med 2018;379:2220-9.

8. van Meerbeeck JP, Fennell DA, De Ruysscher DK. Small-cell lung cancer. Lancet (London, England) 2011;378:1741-55.

9. Meert AP, Paesmans M, Berghmans T, et al. Prophylactic cranial irradiation in small cell lung cancer: a systematic review of the literature with meta-analysis. BMC Cancer 2001;1:5.

10. AstraZeneca. Durvalumab \pm Tremelimumab in Combination With Platinum Based Chemotherapy in Untreated Extensive-Stage Small Cell Lung Cancer (CASPIAN) NCT03043872: ClinicalTrials.gov; 2019. Available online: https://clinicaltrials.gov/ct2/show/record/ NCT03043872 
11. Trials AF. Pembrolizumab vs Topotecan in Patients With Small Cell Lung Cancer: ClinicalTrials.gov; 2019. Available online: https://clinicaltrials.gov/ct2/show/ NCT02963090

12. Corp. MSD. A Study of Pembrolizumab (MK-3475) in Combination With Etoposide/Platinum (Cisplatin or Carboplatin) for Participants With Extensive Stage Small Cell Lung Cancer (MK-3475-604/KEYNOTE-604): ClinicalTrials.gov; 2020. Available online: https:// clinicaltrials.gov/ct2/show/study/NCT03066778

13. Povsic M, Enstone A, Wyn R, et al. Real-world effectiveness and tolerability of small-cell lung cancer (SCLC) treatments: A systematic literature review (SLR). PLoS One 2019;14:e219622.

14. Moher D, Liberati A, Tetzlaff J, et al. Preferred reporting items for systematic reviews and meta-analyses: the PRISMA statement. PLoS Med 2009;6:e1000097.

15. Šćepanović DD, Bajić ND, Živković D, et al. The role of higher thoracic irradiation doses in patients with limited stage of small-cell lung cancer - retrospective study. Arch Oncol 2010;18:8-13.

16. Postmus PE, Quoix E, Ardizzioni A, et al. Small cell lung cancer in daily practice; scot registry (small cell lung cancer treatment and outcome). J Thorac Oncol 2013;8:S339.

17. Yan X, Wang Q, Wang H, et al. Apatinib as maintenance therapy in extensive-stage small-cell lung cancer: results from a single-center retrospective study. J Cancer Res Clin Oncol 2019;145:235-40.

18. Sone H, Igawa S, Kasajima M, et al. Amrubicin monotherapy for elderly patients with relapsed extensivedisease small-cell lung cancer: A retrospective study. Thorac Cancer 2018;9:1279-84.

19. Saber M, Ismail Y, Alieldin N, et al. Neuroendocrine tumors of the lung: A five-year retrospective experience of Egyptian NCI (2010-2014). J Egypt Natl Canc Inst 2018;30:151-8.

20. Qiu G, Du X, Zhou X, et al. Prophylactic cranial irradiation in 399 patients with limited-stage small cell lung cancer. Oncol Lett 2016;11:2654-60.

21. Morise M, Niho S, Umemura S, et al. Low-dose irinotecan as a second-line chemotherapy for recurrent small cell lung cancer. Jpn J Clin Oncol 2014;44:846-51.

22. Chen Y, Li J, Hu Y, et al. Prophylactic cranial irradiation could improve overall survival in patients with extensive small cell lung cancer: A retrospective study. Strahlenther Onkol 2016;192:905-12.

23. Itotani R, Marumo S, Uyama M, et al. The efficacy and safety of carboplatin and weekly paclitaxel combination therapy for previously treated small cell lung cancer patients with interstitial lung disease. Respirology 2017;22:75.

24. Asai N, Ohkuni Y, Matsunuma R, et al. Efficacy and safety of amurubicin for the elderly patients with refractory relapsed small cell lung cancer as third-line chemotherapy. J Cancer Res Ther 2012;8:266-71.

25. Duarte RLM, Luiz RR, Paschoal MEM. The cigarette burden (measured by the number of pack-years smoked) negatively impacts the response rate to platinum-based chemotherapy in lung cancer patients. Lung Cancer 2008;61:244-54.

26. El Benna H, Gabsi A, Mejri N, et al. Small cell lung cancer in good performance status: A mono-center tunisian study. Int J Cancer Manag 2018;11;e9355.

27. Fisher S, Al-Fayea TM, Winget $M$, et al. Uptake and tolerance of chemotherapy in elderly patients with small cell lung cancer and impact on survival. J Cancer Epidemiol 2012;2012:708936.

28. Granados ALO, Caro NL, Pozo JFM, et al. Outcomes of patients with relapsed small-cell lung cancer treated with paclitaxel plus gemcitabine. 10 year-analysis. J Thorac Oncol 2017;12:S700-S1.

29. Hermes A, Waschki B, Gatzemeier U, et al. Characteristics, treatment patterns and outcomes of patients with small cell lung cancer-A retrospective single institution analysis. Lung Cancer 2011;71:363-6.

30. Li J, Chen P, Dai CH, et al. Outcome and treatment in elderly patients with small cell lung cancer: A retrospective study. Geriatr Gerontol Int 2009;9:172-82.

31. Li-Ming X, Zhao LJ, Simone CB 2nd, et al. Receipt of thoracic radiation therapy and radiotherapy dose are correlated with outcomes in a retrospective study of three hundred and six patients with extensive stage small-cell lung cancer. Radiother Oncol 2017;125:331-7.

32. Luan Z, Wang Z, Huang W, et al. Efficacy of 3D conformal thoracic radiotherapy for extensive-stage smallcell lung cancer: A retrospective study. Exp Ther Med 2015;10:671-8.

33. Ploenes T, Osei-Agyemang T, Krohn A, et al. Surgical treatment of early stage small cell lung cancer. Asian Cardiovasc Thorac Ann 2012;20:694-8.

34. Stanic K, Kovac V. Prophylactic cranial irradiation in patients with small-cell lung cancer: The experience at the Institute of Oncology Ljubljana. Radiol Oncol 2010;44:180-6.

35. Zhu H, Guo H, Shi F, et al. Prophylactic cranial irradiation improved the overall survival of patients with surgically 
resected small cell lung cancer, but not for stage I disease. Lung Cancer 2014;86:334-8.

36. Zhu H, Zhou Z, Wang Y, et al. Thoracic radiation therapy improves the overall survival of patients with extensivestage small cell lung cancer with distant metastasis. Cancer 2011;117:5423-31.

37. Govindan R, Page N, Morgensztern D, et al. Changing Epidemiology of Small-Cell Lung Cancer in the United States Over the Last 30 Years: Analysis of the Surveillance, Epidemiologic, and End Results Database. J Clin Oncol 2006;24:4539-44.

38. Srivastava A, Shelly K, Lin F. Prophylactic cranial irradiation in patients with extensive-stage small cell lung cancer (ES-SCLC): A tertiary cancer centre experience. J Thorac Oncol 2018;13:S46-7.

39. Matutino A, Mak MP, Takahashi TK, et al. Prophylactic Cranial Irradiation for Extensive-Stage Small-Cell Lung Cancer: A Retrospective Analysis. J Glob Oncol 2018;4:1-7.

40. Aktas G, Kus T, Kalender ME, et al. Survival analysis in second-line and third-line chemotherapy with irinotecan followed by topotecan or topotecan followed by irinotecan for extensive-stage small-cell lung cancer patients: A single-center retrospective study. Onco Targets Ther 2016;9:1921-6.

41. Tada T, Hosono M, Takada Y, et al. Limitedstage small cell lung cancer: Local failure after concurrent chemoradiotherapy with use of accelerated hyperfractionation. Jpn J Radiol 2010;28:43-7.

42. Wzietek I, Nowara E, Suwinski R. Impact of total thoracic radiation dose and dose fractionation on overall survival in limited-disease small cell lung cancer: A retrospective study on 456 patients. Int J Radiat Oncol Biol Phys 2011;81:S588-9.

43. Morimoto M, Atagi S, Akira M, et al. Overall treatment time of accelerated hyperfractionated radiation therapy at 45 Gy in 30 fractions for limited small cell lung cancer is a significant prognostic factor. Int J Radiat Oncol Biol Phys 2014;90:S646.

44. Sas-Korczyńska B, Łuczyńska E, Kamzol W, et al. Analysis of risk factors for pulmonary complications in patients with limited-stage small cell lung cancer: A single-centre retrospective study. Strahlenther Onkol 2017;193:141-9.

45. Ohara S, Kanda S, Okuma H, et al. Effect of sequential chemoradiotherapy in patients with limited-disease smallcell lung cancer who were ineligible for concurrent therapy: a retrospective study at two institutions. Jpn J Clin Oncol 2018;48:82-8.
46. Inanc M, Bozkurt O, Ocak Dran O, et al. Pretreatment inflammatory indexes are associated with response to firstline platinum- based chemotherapy and prognosis of small cell lung cancer patients. Uluslararasi Hematoloji-Onkoloji Dergisi 2019;29:79-87.

47. Matsuura K, Hirokawa J, Katsuta T, et al. Preliminary Results of a Prospective Study of Accelerated Hyperfractionated Thoracic Radiotherapy with Dose Escalation to 54 Gy for Limited-Stage Small-Cell Lung Cancer. Int J Radiat Oncol Biol Phys 2019;105:E548-9.

48. Forde C, Hussain A, Campbell L, et al. A retrospective audit of the clinical management of extensive stage small cell lung cancer in Northern Ireland. Lung Cancer 2012;75:S57.

49. Kim JS, Choi YJ, Kang EJ. Clinical prognostic factors of elderly patients with extensive stage small cell lung cancer in Korea. J Thorac Oncol 2017;12:S2047.

50. Mellemgaard A, Hersby DS, Chaudhary FN, et al. Retrospective analysis to compare the efficacy of oral (O) vs. intravenous (IV) etoposide given in combination with carboplatin for small cell lung cancer (SCLC), extensive disease (ED). J Clin Oncol 2017;35:e20020.

51. Elegbede A, Dean M, Bebb G. P1.12-11 2010 -2015

Extensive Stage SCLC Diagnoses in a Canadian Institution: Baseline Characteristics That Impact on the Overall Survival. J Thorac Oncol 2018;13:S577.

52. Sallam M, Wong H, Escriu C. 1669PTreatment beyond four cycles of first line platinum and etoposide chemotherapy in real-life patients with stage IV small cell lung cancer: A retrospective study of the Merseyside and Cheshire cancer network. Ann Oncol 2018;29.

53. Sedef AM, Çalikuşu Z, Bahçeci A, et al. The prognostic significance of complete response rates in patients with extensive stage small cell lung cancer. Turk Onkoloji Dergisi 2019;34:45-8.

54. Shirasawa M, Fukui T, Kusuhara S, et al. Efficacy and risk of cytotoxic chemotherapy in extensive disease-small cell lung cancer patients with interstitial pneumonia. BMC Cancer 2019;19.

55. Sukauichai S. EP1.16-35 Survival of Patients with Small Cell Lung Cancer at a Cancer Hospital in Thailand, $2007-$ 2016. J Thorac Oncol 2019;14:S1077-8.

56. Zhang J, Li S, Chen X, et al. Retrospective study of surgery versus non-surgical management in limited-disease small cell lung cancer. Thorac Cancer 2014;5:405-10.

57. Aynaci Ö, Canyilmaz E, Serdar L, et al. Survival and prognostic factors in limited stage small cell lung cancer: A retrospective study from northeast Turkey. J Cancer Res 
Ther 2016;12:238-43.

58. Al Farsi A, Swaminath A, Ellis P. Patterns of relapse in Small Cell Lung Cancer (SCLC): A retrospective analysis of outcomes from a Single Canadian Center. J Thorac Oncol 2017;12:S727-8.

59. Islam M, Sanmugarajah J, Conroy S, et al. Treatment outcome for the elderly patients with small cell lung cancer. Asia Pac J Clin Oncol 2015;11:128.

60. Chen XR, Liang JZ, Ma SX, et al. Consolidation chemotherapy improves progression-free survival in stage III small-cell lung cancer following concurrent chemoradiotherapy: A retrospective study. Onco Targets Ther 2016;9:5729-36.

61. Inomata M, Hayashi R, Tokui K, et al. Outcome and prognostic factors in patients with small cell lung cancer who receive third-line chemotherapy. Tumori 2014;100:507-11.

62. Murakami Y, Saka H, Oki M, et al. Efficacy of platinum re-challenge chemotherapy in sensitive relapsed small cell lung cancer after a long-term treatment-free interval. J Clin Oncol 2015;33.

63. Minemura H, Imai H, Sugiyama T, et al. A retrospective study of amrubicin monotherapy for the treatment of relapsed small cell lung cancer in elderly patients. J Thorac Oncol 2017;12:S2044.

64. Zhang L, Liu X, Cheng Y. Combined Chemotherapy Versus Topotecan Monotherapy as Second-Line Treatment for Patients with Sensitive Relapsed SCLC. J Thorac Oncol 2018;13:S1088.

65. von Eiff D, Bozorgmehr F, Christopoulos P, et al. 1675PRetrospective study of paclitaxel in advanced therapy lines in the treatment of SCLC. Ann Oncol 2018;29.

66. Yu S, Wang Y. Irinotecan in combination with platinum in refractory or relapsed small cell lung cancer. J Clin Oncol $2013 ; 31$.

67. Wang Y, Xu J, Han B, et al. The role of prophylactic cranial irradiation in surgically resected combined small cell lung cancer: A retrospective study. J Thorac Dis 2018;10:3418-27.

68. Matsuura K, Katsuta T, Kagemoto M. 45 Gy versus 54 Gy of accelerated hyperfractionated thoracic radiotherapy for patients with limited-stage small-cell lung cancer. J Clin Oncol 2016;34:e20104.

69. Chen H, Ali E, Palma D, et al. Effectiveness of Hypofractionated Thoracic Radiotherapy in Limited-Stage Small-Cell Lung Cancer: A Propensity Score Analysis. J Thorac Oncol 2018;13:S795-6.

70. Nakahara Y, Hosomi Y, Akahane M, et al. Retrospective study of prophylactic cranial irradiation in small-cell lung cancer: Neurocognitive analysis. Ann Oncol 2012;23:xi145.

71. Moharana L, Lokanatha D, Jacob LA, et al. A study in recurrent small cell lung cancer patients, comparing weekly paclitaxel, irinotecan and temozolomide in secondline: A prospective study from a south Indian tertiary cancer hospital. Ann Oncol 2019;30:ix176.

72. Zhao Y, Wan B, Zhang T, et al. Irinotecan, topotecan, paclitaxel or docetaxel for second-line treatment of small cell lung cancer: A single-center retrospective study of efficiency comparation and prognosis analysis. Transl Lung Cancer Res 2019;8:829-37.

73. Saijo A, Hanibuchi M, Ogino H, et al. Paclitaxel for relapsed small-cell lung cancer patients with idiopathic interstitial pneumonias. Mol Clin Oncol 2019;10:541-6.

74. Moser SS, Bar J, Khan I, et al. EP1.12-21 Treatment Patterns and Prognostic Factors in Small-Cell Lung Cancer Patients in Israel - Real World Analysis of a Health Services Database. J Thorac Oncol 2019;14:S1024.

75. Sugiyama K, Kogure Y, Torii A, et al. Solvent-based paclitaxel or nab-paclitaxel for heavily treated relapsed/ refractory small cell lung cancer: Retrospective singleinstitution observational study. Medicine 2019;98:e14758.

76. Ogawa S, Horio Y, Yatabe Y, et al. Patterns of recurrence and outcome in patients with surgically resected small cell lung cancer. Int J Clin Oncol 2012;17:218-24.

77. Zheng Q, Li S, Zhang L, et al. Retrospective study of surgical resection in the treatment of limited stage small cell lung cancer. Thorac Cancer 2013;4:395-9.

78. Bagshaw HP, Taggarsi RS, Moding EJ, et al. Stereotactic Radiosurgery for Small Cell Lung Cancer Brain Metastases. Int J Radiat Oncol Biol Phys 2019;105:E70-1.

79. Cifarelli CP, Vargo JA, Fang W, et al. Role of Gamma Knife Radiosurgery in Small Cell Lung Cancer: A MultiInstitutional Retrospective Study of the International Radiosurgery Research Foundation (IRRF). Neurosurgery 2020;87:664-71.

80. Sugiyama T, Hirose T, Hosaka T, et al. Effectiveness of intensive follow-up after response in patients with small cell lung cancer. Lung Cancer 2008;59:255-61.

81. Ramlov A, Tietze A, Khalil AA, et al. Prophylactic cranial irradiation in patients with small cell lung cancer. A retrospective study of recurrence, survival and morbidity. Lung Cancer 2012;77:561-6.

82. Ozawa Y, Omae M, Fujii M, et al. Retrospective evaluation of prophylactic cranial irradiation in patients with limitedstage small cell lung cancer with stereotactic radiotherapy: A multi-institutional study. J Clin Oncol 2014;32. 
83. Bang A, Kendal W, Cook G, et al. Prophylactic cranial irradiation in extensive stage small cell lung cancer: The Ottawa hospital experience. J Thorac Oncol 2015;10:S498.

84. Mamesaya N, Wakuda K, Kotake M, et al. Prophylactic cranial irradiation (PCI) in limited-disease small-cell lung cancer (LDSCLC) patients with brain imaging. J Clin Oncol 2017;35:abstr e20010.

85. Soon YY, Zheng H, Ho SZ, et al. Adoption of prophylactic cranial irradiation (PCI) for extensive stage small cell lung cancer (ES-SCLC): a population based outcome study. Radiat Oncol 2018;13:247.

86. Boskovic T, Secen N, Vitorovic S, et al. EP1.12-04 Can Prophylactic Cranial Irradiation Reduce Neurological Symptoms in Patients with Small Cell Lung Cancer? J Thorac Oncol 2019;14:S1017.

87. Liu X, Zhou Z, Dong X, et al. Efficacy and Failure Patterns of Prophylactic Cranial Irradiation in Patients with Limited-stage Small Cell Lung Cancer Who Were Estimated by Modern Brain Imaging and Treated with Standard Chemoradiotherapy. Int J Radiat Oncol Biol Phys 2019;105:E548.

88. Cabrero DS, Cruz P, Martinez S, et al. EP1.12-26

Retrospective Study About the Impact of Brain Metastases and Cranial Irradiation in Small Cell Lung Cancer. J Thorac Oncol 2019;14:S1027.

89. Chung J, Kang SY, Cheon GJ, et al. Role of Prophylactic Cranial Irradiation in Extensive Disease Small Cell Lung Cancer. Radiother Oncol 2019;133:S398.

90. De Ruysscher D, Pijls-Johannesma M, Bentzen SM, et al.

Cite this article as: Johal S, Hettle R, Carroll J, Maguire P, Wynne T. Real-world treatment patterns and outcomes in small-cell lung cancer: a systematic literature review. J Thorac Dis 2021;13(6):3692-3707. doi: 10.21037/jtd-20-3034
Time between the first day of chemotherapy and the last day of chest radiation is the most important predictor of survival in limited-disease small-cell lung cancer. J Clin Oncol 2006;24:1057-63.

91. Blackstock AW, Bogart JA, Matthews C, et al. Split-course versus continuous thoracic radiation therapy for limitedstage small-cell lung cancer: final report of a randomized phase III trial. Clin Lung Cancer 2005;6:287-92.

92. Rossi A, Di Maio M, Chiodini P, et al. Carboplatin- or cisplatin-based chemotherapy in first-line treatment of small-cell lung cancer: the COCIS meta-analysis of individual patient data. J Clin Oncol 2012;30:1692-8.

93. Foster NR, Qi Y, Shi Q, et al. Tumor response and progression-free survival as potential surrogate endpoints for overall survival in extensive stage small-cell lung cancer: findings on the basis of North Central Cancer Treatment Group trials. Cancer 2011;117:1262-71.

94. Dong XJ, Wang MZ, Zhong W, et al. A retrospective study for the limited stage small cell lung cancer with multidisciplinary treatment. Respirology 2011;16:144.

95. Cope S, Keeping ST, Barazandegan M, et al. Approaches for Estimating the Comparative Efficacy of Treatments for Patients with Recurrent Small Cell Lung Cancer (SCLC) within Connected and Disconnected Networks of Evidence. Value Health 2018;21:S16.

96. Yin X, Yan D, Qiu M, et al. Prophylactic cranial irradiation in small cell lung cancer: a systematic review and metaanalysis. BMC Cancer 2019;19:95. 
Supplementary

Table S1 Search terms used in the Embase databases (search strings adapted for compatibility with other databases)

\begin{tabular}{|c|c|}
\hline \# & Search terms (Embase \& Medline) \\
\hline 2 & small cell carcinoma'/exp \\
\hline 3 & 'sclc' \\
\hline 4 & (pancoast* OR 'superior sulcus' OR 'pulmonary sulcus') NEXT/4 (tumo?r OR syndrome*) \\
\hline 6 & $1-5$ (or) \\
\hline 7 & Observational.tw \\
\hline 8 & (retrospective NEXT/1 study).tw \\
\hline 11 & (expanded NEXT/1 access NEXT/1 program).tw \\
\hline 12 & $7-11(\mathrm{OR})$ \\
\hline 13 & 6 AND 12 \\
\hline 14 & Humans/lim \\
\hline 15 & EM 2000/01 \\
\hline
\end{tabular}

*truncated term - finds variant word endings e.g., child* finds child, childhood, children 
Table S2 Treatments and outcomes reported in the included studies

\begin{tabular}{|c|c|c|c|c|c|c|c|}
\hline Author & Year & Country & Patient characteristics & Treatment received & Regimen & Outcomes & Conclusion \\
\hline \multicolumn{8}{|l|}{ Surgery } \\
\hline Ploenes et al. & 2012 & Germany & $\begin{array}{l}\text { No. of patients }=29 \\
\text { Mean age, years }=62 \\
(46-82) \\
\text { Gender }(\text { male })=75.9 \%\end{array}$ & Surgery $=100 \%$ & $\begin{array}{l}\text { Surgery and CT } \\
\text { [neoadjuvant] }=52 \% \\
\text { Surgery and CT } \\
\text { [Adjuvant] }=48 \%\end{array}$ & $\begin{array}{l}\text { OS (median) }=89.4 \mathrm{mo} \text { (surgery } \\
\text { + neoadjuvant) } 20.4 \mathrm{mo} \\
\text { (surgery) }\end{array}$ & $\begin{array}{l}\text { Surgical resection could be } \\
\text { beneficial in highly selected } \\
\text { patients [cT1-2 cNO cMO disease] } \\
\text { who can be completely resected. } \\
\text { Adjuvant therapy is recommended } \\
\text { following surgery }\end{array}$ \\
\hline Ogawa et al. & 2012 & Japan & $\begin{array}{l}\text { No. of patients }=15 \\
\text { Mean age, years }=64 \\
(54-77) \\
\text { Gender (male) }=92 \%\end{array}$ & $\begin{array}{l}\text { Surgery }=32.7 \% \\
\text { Induction } \mathrm{CT}=33 \% \\
\text { Adjuvant CT }=82 \%\end{array}$ & $\begin{array}{l}\text { Induction } \mathrm{CT}=100 \% \\
{[\mathrm{PE}]} \\
\text { Adjuvant } \mathrm{CT}=76.9 \% \\
{[\mathrm{PE}] \text { Other }=23.1 \%}\end{array}$ & OS $($ median $)=59.2 \mathrm{mo}$ & N/A \\
\hline Zheng et al. & 2013 & China & $\begin{array}{l}\text { No. of patients }=54 \\
\text { Mean age, years }=56 \\
(32-76) \\
\text { Gender (male) }=72 \%\end{array}$ & $\begin{array}{l}\text { Surgery }=66.6 \% \text { [Radical } \\
\text { resection]; } 33.3 \% \text { [Non- } \\
\text { radical resection] } \\
\text { Pre-operative } \\
\text { chemotherapy }=42.6 \%\end{array}$ & N/A & $\begin{array}{l}\text { OS }(5 y r s)=73 \% \text { [Radical } \\
\text { resection and pre-op chemo]; } \\
27 \% \text { [Radical resection and no } \\
\text { pre-op chemo]; } 67 \% \text { [Non- } \\
\text { radical resection and pre-op } \\
\text { chemo ]; } 67 \%[\text { Non-radical } \\
\text { resection and no pre-op } \\
\text { chemo] }\end{array}$ & $\begin{array}{l}\text { Pulmonary resection could } \\
\text { improve survival for patients } \\
\text { with early LS-SCLC. Systemic } \\
\text { chemotherapy is recommended } \\
\text { for all SCLC patients }\end{array}$ \\
\hline Zhang et al. & 2014 & China & $\begin{array}{l}\text { No. of patients }=153 \\
\text { Mean age, years }=56 \\
(23-84) \\
\text { Gender }(\text { male })=73.2 \%\end{array}$ & $\begin{array}{l}\text { Surgery }=32.7 \% \\
\text { CT }=100 \% \\
\text { RDT }=56 \% \\
\mathrm{PCI}=50 \%\end{array}$ & $\begin{array}{l}\text { Surgery and } \mathrm{CT}= \\
78 \% \text { [adjuvant] } 22 \% \\
\text { [neoadjuvant] }\end{array}$ & $\begin{array}{l}\text { OS }(\text { median })=30.5 \mathrm{mo} \\
\text { (surgical) } 16.5 \mathrm{mo} \text { (non- } \\
\text { surgical) }\end{array}$ & $\begin{array}{l}\text { Pulmonary resection could } \\
\text { improve the survival for I-IIIA } \\
\text { stage SCLC. Systemic therapy is } \\
\text { recommended for all patients with } \\
\text { SCLC. }\end{array}$ \\
\hline Bagshaw et al. & 2019 & USA & No. of patients $=59$ & Surgery $=100 \%$ & $\begin{array}{l}\text { Stereotactic radiosur- } \\
\text { gery }=100 \%\end{array}$ & OS $($ median $)=6.2 \mathrm{mo}$ & $\begin{array}{l}\text { Patients with SCLC treated with } \\
\text { SRS appear to have similar rates } \\
\text { of local failure, distant failure, and } \\
\text { neurologic death compared to } \\
\text { historical controls of SRS for non- } \\
\text { SCLC }\end{array}$ \\
\hline Cifarelli et al. & 2019 & International & $\begin{array}{l}\text { No. of patients }=232 \\
\text { Age }(\text { median })=63 \\
\text { Gender }(\text { Male, } \%)=50.5 \%\end{array}$ & Surgery $=100 \%$ & $\begin{array}{l}\text { Gamma knife radiosur- } \\
\text { gery }=100 \%\end{array}$ & $\begin{array}{l}\text { OS }(1 \mathrm{yr})=28 \% \text {; Local failure } \\
(1 \mathrm{yr})=31 \% ; \text { Distant brain } \\
\text { failure }(1 \mathrm{yr})=49 \%\end{array}$ & $\begin{array}{l}\text { SRS plays an important role in the } \\
\text { management of brain metastases } \\
\text { from SCLC, especially in salvage } \\
\text { therapy following WBRT }\end{array}$ \\
\hline \multicolumn{8}{|c|}{ Chemotherapy/Chemoradiotherapy - Limited Stage } \\
\hline Scepanovic et al. & 2010 & Slovakia & $\begin{array}{l}\text { No. of patients }=81 \\
\text { Median age, years }=57 \\
\text { Gender (male) }=80 \%\end{array}$ & $\mathrm{CCRT}=100 \%$ & $\begin{array}{l}\text { CT }[\mathrm{PE}=100 \% ; \\
\text { Minimum }=4 \text { cycles] } \\
\text { RDT [44 Gy in } 22 \\
\text { fractions }=50 \% ; \\
54-64 \text { Gy in } 27 \text { to } 32 \\
\text { fractions }=50 \% \text { ] }\end{array}$ & $\begin{array}{l}\text { OS (1yr) = 98\% (44Gy group), } \\
100 \% \text { ( } 54-64 \text { Gy group) } \\
\text { PFS (1yr) = 42\% (44Gy group), } \\
65 \% \text { ( } 54-64 \text { Gy group) } \\
\text { OS (2yrs) = 5\% (44Gy group), } \\
53 \% \text { (54-64 Gy group) } \\
\text { PFS (2yrs) = } 2 \% \text { (44Gy group), } \\
20 \% \text { (54-64 Gy group) }\end{array}$ & $\begin{array}{l}\text { Higher RDT doses resulted in } \\
\text { improved time to progression and } \\
\text { survival }\end{array}$ \\
\hline Tada et al. & 2010 & Japan & $\begin{array}{l}\text { No. of patients }=30 \\
\text { Gender (male) }=80 \%\end{array}$ & $\begin{array}{l}\mathrm{CCRT}=100 \% \\
\mathrm{PCI}=33.3 \%\end{array}$ & $\begin{array}{l}\mathrm{CT}[\mathrm{PE}=46 \% ; \mathrm{PEI}= \\
27 \% ; \mathrm{PCE}=17 \% ; \\
\mathrm{CE}=10 \%] \\
\text { RDT }[45 \mathrm{~Gy} \text { in } 30 \\
\text { fractions }=100 \%]\end{array}$ & $\begin{array}{l}\text { CR }=83 \% \\
\text { OS }(2 \mathrm{yrs})=54 \% \\
\text { OS }(5 \mathrm{yrs})=26 \%\end{array}$ & N/A \\
\hline
\end{tabular}

Table S2 (continued) 


\begin{tabular}{|c|c|c|c|c|c|c|c|}
\hline Author & Year & Country & Patient characteristics & Treatment received & Regimen & Outcomes & Conclusion \\
\hline Dong et al. & 2011 & China & No. of patients $=166$ & $\begin{array}{l}\text { CCRT }=29.5 \% \\
\text { SCRT }=37.3 \% \\
\mathrm{CT}=33.2 \%\end{array}$ & $\begin{array}{l}\mathrm{CT}[\mathrm{CE} / \mathrm{PE}=100 \%] \\
\mathrm{RDT}[\mathrm{Mean}=49.6 \mathrm{~Gy}]\end{array}$ & $\begin{array}{l}\text { ORR }=89.4 \% \text { (CCRT), } 67.2 \% \\
\text { (SCRT), 66\% (CT) } \\
\text { OS (median) = 29.7mo (CCRT), } \\
22.6 \text { mo (SCRT), } 19.5 \text { mo (CT) } \\
\text { PFS (median) = 12.7mo } \\
\text { (CCRT), 10.8mo (SCRT), } \\
\text { 10.8mo (CT) }\end{array}$ & $\begin{array}{l}\text { Chemoradiotherapy produce } \\
\text { superior survival outcomes to CT } \\
\text { alone. Similarly, CCRT results in } \\
\text { increased survival vs SCRT }\end{array}$ \\
\hline Hermes et al. & 2011 & Germany & $\begin{array}{l}\text { No. of patients }=155 \\
\text { Median age, years }=63\end{array}$ & $\mathrm{CT}=100 \%$ & $\mathrm{CT}[\mathrm{CE}=100 \%]$ & $\begin{array}{l}\text { Median OS }=18.7 \mathrm{mo}(1-4 \\
\text { cycles) } 18.5 \mathrm{mo}(5-6 \text { cycles })\end{array}$ & $\begin{array}{l}\text { No. of cycles has limited impact } \\
\text { on survival for patients with LS } \\
\text { disease }\end{array}$ \\
\hline Wzietek et al. & 2011 & Poland & No. of patients $=456$ & $\begin{array}{l}\mathrm{CCRT}=100 \% \\
\mathrm{PCI}=37 \%\end{array}$ & $\begin{array}{l}\text { CT [PE = 100\%] } \\
\text { RDT dosing a) <45Gy } \\
\text { b) } 45 \mathrm{~Gy} \mathrm{c)} 45-54 \mathrm{~Gy} \\
\text { d) }>54 \mathrm{~Gy} \text { [No patient } \\
\text { numbers provided ] }\end{array}$ & $\begin{array}{l}\text { OS (1yrs) }=5 \% \quad(<45 G y) ; 25 \% \\
(45 G y), 12 \% \\
(45-54 G y), 15 \% \text { (>54Gy) }\end{array}$ & $\begin{array}{l}\text { Higher dose TRT doses failed } \\
\text { to show any survival advantage } \\
\text { compared with standard doses } \\
\text { (e.g. } 45 \text { Gy) }\end{array}$ \\
\hline Morimoto et al. & 2014 & Japan & No. of patients $=81$ & $\mathrm{CCRT}=100 \%$ & $\begin{array}{l}\mathrm{CT}[\mathrm{CE}=19 \% ; \mathrm{PE}= \\
81 \%] \\
\mathrm{RDT}[45 \mathrm{~Gy} \text { in } 30 \\
\text { fractions }=100 \% ; \\
\text { Median overall } \\
\text { treatment time }=24 \\
\text { days }\end{array}$ & N/A & N/A \\
\hline Aynaci et al. & 2016 & Turkey & $\begin{array}{l}\text { No. of patients }=129 \\
\text { Mean age, years }=60.1 \\
\text { Gender }(\text { male })=96.9\end{array}$ & $\begin{array}{l}\mathrm{CCRT}=8 \% \\
\mathrm{SCRT}=76 \% \\
\mathrm{PCI}=31.2 \%\end{array}$ & $\begin{array}{l}\mathrm{CT}[\mathrm{CE}=89 \% ; \mathrm{CAV}= \\
6.9] \\
\mathrm{RDT}[>50 \mathrm{~Gy}=50 \%]\end{array}$ & $\begin{array}{l}\mathrm{OS}(\text { median })=13.9 \mathrm{mo} \\
\mathrm{DFS}(\text { median })=18 \mathrm{mo}\end{array}$ & $\begin{array}{l}\text { CCRT and }>50 \text { Gy provide an } \\
\text { improved OS/DFS over SCRT }\end{array}$ \\
\hline Matsuura et al. & 2016 & Japan & No. of patients $=19$ & $\mathrm{CCRT}=100 \%$ & $\begin{array}{l}\text { CT [CE or PE - no. of } \\
\text { patients not stated] } \\
\text { RDT [ } 45 \text { Gy in } 30 \\
\text { fractions = } 47.3 \% ; 54 \\
\text { Gy in } 36 \text { fractions = } \\
52.8 \% \text { ] }\end{array}$ & $\begin{array}{l}\text { Median OS = } 24 \text { mo ( } 45 \text { Gy } \\
\text { group), } 41 \mathrm{mo} \text { ( } 54 \text { Gy group) } \\
\text { OS (3yrs) = 33.3\% ( } 45 \text { Gy } \\
\text { group), } 60 \% \text { ( } 54 \text { Gy group) } \\
\text { PFS (3yrs) = 0\% ( } 45 \text { Gy group), } \\
40 \% \text { (54 Gy group) }\end{array}$ & $\begin{array}{l}\text { CCRT with } 54 \text { Gy results in slower } \\
\text { time to progression and improved } \\
\text { survival without increased toxicity, } \\
\text { compared to } 45 \text { Gy }\end{array}$ \\
\hline Chen et al. & 2016 & China & $\begin{array}{l}\text { No. of patients }=177 \\
\text { Gender (male) }=87 \%\end{array}$ & $\begin{array}{l}\text { CCCT }=100 \% \text { CCRT }= \\
100 \% \\
\text { Followed by consolidation } \\
\text { CT }=40.6 \% \\
\mathrm{PCI}=61.5 \%\end{array}$ & $\begin{array}{l}\mathrm{CT} \text { (induction) }[\mathrm{PE}= \\
100 \%] \\
\mathrm{RDT}=100 \%] \\
\text { Consolidation CT } \\
\text { [TOP = 60\%; Other }= \\
40 \%]\end{array}$ & $\begin{array}{l}\text { PFS }(\text { Median })=17 \mathrm{mo}(\mathrm{CCRT}), \\
12.9 \mathrm{mo}(\text { non-CCT) } \\
\text { OS }(\text { Median })=31.6 \mathrm{mo}(\mathrm{CCRT}) \\
24.8 \mathrm{mo}(\text { non-CCT) }\end{array}$ & $\begin{array}{l}\text { Consolidation CT can improve } \\
\text { survival outcomes following initial } \\
\text { treatment with CCRT }\end{array}$ \\
\hline Sas-Korczyńska et al. & 2017 & Poland & $\begin{array}{l}\text { No. of patients }=217 \\
\text { Mean age, years }=60.3 \\
\text { Gender }(\text { male })=65 \%\end{array}$ & $\begin{array}{l}\mathrm{CCRT}=46.5 \% \\
\mathrm{SCRT}=53.5 \% \\
\mathrm{PCI}=60.4 \%\end{array}$ & $\begin{array}{l}\text { CT }[P E=100 \% \text {; Mean } \\
\text { no. of cycles }=4.9] \\
\text { RDT [TRT dose }=40- \\
66]\end{array}$ & $\begin{array}{l}\text { DFS (5yrs) = 28\% mo (CCRT); } \\
14.3 \%(\mathrm{SCRT}) \\
\text { OS (5yrs) = 27.3\% (CCRT); } \\
11.7 \% \text { (SCRT) }\end{array}$ & $\begin{array}{l}\text { CCRT leads to improved survival } \\
\text { outcomes, delayed thoracic } \\
\text { reoccurrence and reduced distant } \\
\text { metastases vs SCRT }\end{array}$ \\
\hline Chen et al. & 2018 & China & No. of patients $=118$ & $\begin{array}{l}\mathrm{HFRT}=48.3 \% \\
\mathrm{CFRT}=51.7 \%\end{array}$ & & $\begin{array}{l}\text { OS }(5 y r s)=26 \%(\text { HFRT), } 24 \% \\
\text { (CFRT) } \\
\text { PFS (5yrs) }=22 \%(\text { HFRT), } 22 \% \\
\text { (CFRT) }\end{array}$ & $\begin{array}{l}\text { HFRT and CFRT produce similar } \\
\text { survival outcomes. HFRT was } \\
\text { associated with reduced toxicities }\end{array}$ \\
\hline
\end{tabular}

Table S2 (continued) 


\begin{tabular}{|c|c|c|c|c|c|c|c|}
\hline Author & Year & Country & Patient characteristics & Treatment received & Regimen & Outcomes & Conclusion \\
\hline O Hara et al. & 2018 & Japan & $\begin{array}{l}\text { No. of patients }=254 \\
\text { Mean age, years }=64 \\
\text { Gender }(\text { male })=77.1 \%\end{array}$ & $\begin{array}{l}\text { CCRT }=61 \% \\
\text { SCRT }=12 \% \\
\text { CT }=16 \% \\
\mathrm{PCI}=38.5 \%\end{array}$ & $\begin{array}{l}\mathrm{CT}[\mathrm{CE}=22.8 \% ; \mathrm{PE}= \\
54.7 \% \%] \\
\text { RDT [45 GY in } 1.5 \\
\text { fractions twice a day } \\
=62.8 \% ; 50 \text { Gy in } 25 \\
\text { fractions }=18.5 \% \text {; No } \\
\text { RDT }=16 \% \text { \} }\end{array}$ & $\begin{array}{l}\text { Complete tumour response } \\
=35 \%(\mathrm{CCRT}) ; 18 \% \text { (SCRT); } \\
11 \% \text { (CT) } \\
\text { OS (Median) = } 41.1 \mathrm{mo} \\
\text { (CCRT); 38.1mo (SCRT); } \\
\text { 15.6mo (CT) } \\
\text { OS (5yrs) = 41\% (CCRT); 36\% } \\
\text { (SCRT); } 15.4 \% \text { (CT) }\end{array}$ & $\begin{array}{l}\text { SCRT produce comparable } \\
\text { treatment outcomes to CCRT }\end{array}$ \\
\hline Sukauichai et al. & 2019 & Thailand & $\begin{array}{l}\text { No. of patients }=35 \\
\text { Age }(\text { median })=61 \\
\text { Gender (Male, } \%)=83 \%\end{array}$ & $\begin{array}{l}\mathrm{CT}=80 \% \\
\mathrm{PCl}=3 \%\end{array}$ & $\begin{array}{l}\text { CT }[P E=51.4 \% ; \\
C E=28.7 \%]\end{array}$ & $\begin{array}{l}\text { OS }(\text { Median })=17.7 \mathrm{mo}(\text { LS }) \\
5.9 \mathrm{mo}(\mathrm{ES})\end{array}$ & $\begin{array}{l}\text { The OS of the limited stage } \\
\text { SCLC patients at our hospital } \\
\text { was comparable to landmark } \\
\text { studies. Most received sequential } \\
\text { chemoradiation treatment }\end{array}$ \\
\hline Matsuura et al. & 2019 & Japan & No. of patients $=13$ & $\mathrm{CCRT}=100 \%$ & $\begin{array}{l}\mathrm{CT}[\mathrm{PE} / \mathrm{CE}=100 \%] \\
\mathrm{RDT}[54 \mathrm{~Gy} \text { in } 36 \\
\text { fractions in } 18 \\
\text { days }=100 \%]\end{array}$ & $\begin{array}{l}\text { OS }(1 \mathrm{yr})=100 \% ; \text { OS }(2 \mathrm{yrs}) \\
=92.3 \% ; \text { OS }(3 \mathrm{yrs})=72.5 \% \\
\text { PFS }(1 \mathrm{yr})=76.9 \% ; \text { PFS }(2 \mathrm{yrs}) \\
=53.9 \% ; \text { PFS }(3 \mathrm{yrs})=53.9 \%\end{array}$ & $\begin{array}{l}\text { AHF-TRT of } 54 \text { Gy with concur- } \\
\text { rent PE or CE regimens resulted } \\
\text { in a better OS and PFS without an } \\
\text { increase in the severity of toxicity }\end{array}$ \\
\hline \multicolumn{8}{|c|}{ Chemotherapy/Chemoradiotherapy - Extensive stage } \\
\hline Zhu et al. & 2011 & China & $\begin{array}{l}\text { No. of patients }=119 \\
\text { Mean age, years }=61 \\
\text { Gender (male) }=80.7 \%\end{array}$ & $\begin{array}{l}\mathrm{CT}=49.6 \% \\
\mathrm{CRT}=50.4 \% \\
\mathrm{PCI}=1.6 \%\end{array}$ & $\begin{array}{l}\mathrm{CT}[\mathrm{PE}=87.4 \% ; \mathrm{CE}= \\
12.6 \%] \\
\mathrm{CRT}=40-60 \mathrm{~Gy} \\
\mathrm{PCI}=1.6 \%\end{array}$ & $\begin{array}{l}\text { OS (median) = 17mo (CRT), } \\
9.3 \mathrm{mo}(\mathrm{CT}) \\
\text { OS (2yr) }=35 \% \text { (CRT), } 17 \% \\
\text { (CT) } \\
\text { OS (5yr) }=7.1 \% \text { (CRT), } 5.1 \% \\
\text { (CT) }\end{array}$ & $\begin{array}{l}\text { TRT added to CT improved OS in } \\
\text { ES-SCLC patients. }\end{array}$ \\
\hline Forde et al. & 2012 & UK & No. of patients $=81$ & $\begin{array}{l}\text { CT }=39 \% \\
\text { SCRT }=61 \%\end{array}$ & Not available & N/A & $\mathrm{N} / \mathrm{A}$ \\
\hline Luan et al. & 2015 & China & $\begin{array}{l}\text { No. of patients }=167 \\
\text { Mean age, years }=59 \\
\text { Gender (male) }=82.6 \%\end{array}$ & $\begin{array}{l}\mathrm{CT}=50.1 \% \\
\mathrm{CCRT}=49.1 \% \\
\mathrm{PCI}=2.9 \%\end{array}$ & $\begin{array}{l}\mathrm{CT}[\mathrm{PE}=77 \% ; \mathrm{CE}= \\
23 \%]\end{array}$ & $\begin{array}{l}\text { OS (median) = 18mo (CCRT), } \\
12 \mathrm{mo}(\mathrm{CT}) \\
\text { PFS (median) }=9 \mathrm{mo}(\mathrm{CCRT}) \\
6 \mathrm{mo}(\mathrm{CT}) \\
\text { OS }(2 \mathrm{yrs})=35.3 \% \text { (CCRT), } \\
14.5 \%(\mathrm{CT}) \\
\text { OS (5yrs) }=2.4 \%(\mathrm{CCRT}) \\
2.4 \%(\mathrm{CT})\end{array}$ & $\begin{array}{l}\text { TRT added to CT improved OS in } \\
\text { ES-SCLC patients. }\end{array}$ \\
\hline Kim et al. & 2017 & Korea & $\begin{array}{l}\text { No. of patients }=88 \\
\text { Mean age, years }=71 \\
{[65-83]} \\
\text { Gender (male) }=82 \%\end{array}$ & $\mathrm{CT}=100 \%$ & $\begin{array}{l}\text { CT [etoposide-based } \\
\text { regimen }=100 \% \text { ] }\end{array}$ & N/A & $\mathrm{N} / \mathrm{A}$ \\
\hline Li-Ming et al. & 2017 & China & $\begin{array}{l}\text { No. of patients }=306 \\
\text { Mean age, years }=60 \\
\text { Gender (male) }=72 \%\end{array}$ & $\begin{array}{l}\mathrm{CT}=55.5 \% \\
\mathrm{CCRT}=44.5 \% \\
\mathrm{PCI}=8.8 \%\end{array}$ & $\begin{array}{l}\mathrm{CT}[\text { etoposide-based } \\
\text { regimen }=100 \%]\end{array}$ & $\begin{array}{l}\text { OS }(2 \mathrm{yrs})=21.4 \%(\mathrm{CCRT}) \\
10.3 \%(\mathrm{CT}) \\
\text { PFS (2yrs) }=7.7 \%(\mathrm{CCRT}) \\
4.6 \%(\mathrm{CT})\end{array}$ & $\begin{array}{l}\text { TRT added to CT improved OS } \\
\text { in ES-SCLC patients. High TRT } \\
\text { doses improved OS over lower } \\
\text { doses }\end{array}$ \\
\hline Mellemgaard et al. & 2017 & Denmark & No. of patients $=200$ & $\mathrm{CT}=100 \%$ & $\begin{array}{l}\text { CT [oral etoposide }= \\
42 \% \text {; IV etoposide= } \\
58 \% \text { ] }\end{array}$ & $\begin{array}{l}\text { OS (median) }=227 \text { days } \\
\text { (etoposide oral), } 235 \text { days } \\
\text { (etoposide IV) } \\
\text { PFS (median) = } 140 \text { days } \\
\text { (etoposide oral), } 195 \\
\text { days(etoposide IV) }\end{array}$ & $\begin{array}{l}\text { IV and oral produced similar } \\
\text { OS but longer PFS with the IV } \\
\text { schedule for ES-SCLC }\end{array}$ \\
\hline
\end{tabular}

Table S2 (continued) 
Table S2 (continued)

\begin{tabular}{|c|c|c|c|c|c|c|c|}
\hline Author & Year & Country & Patient characteristics & Treatment received & Regimen & Outcomes & Conclusion \\
\hline Elegbede et al. & 2018 & Canada & $\begin{array}{l}\text { No. of patients }=242 \\
\text { Mean age, years }=68\end{array}$ & $\begin{array}{l}\mathrm{CT}=40 \% \\
\mathrm{CRT}=60 \% \\
\mathrm{PCI}=12.4 \%\end{array}$ & Not available & $\mathrm{N} / \mathrm{A}$ & $\begin{array}{l}\text { In contrast to advanced NSCLC, } \\
\text { systemic treatment uptake was } \\
\text { high. However, }<20 \% \text { of patients } \\
\text { followed through with PCI }\end{array}$ \\
\hline Sallam et al. & 2018 & UK & No. of patients $=671$ & $\mathrm{CT}=100 \%$ & $\begin{array}{l}{[\mathrm{CE}=94 \% ; \mathrm{PE}=6 \%]} \\
\text { Platinum }+\mathrm{E}(4 \text { cycles }) \\
=86 \% ; \text { Platinum + E } \\
(>4 \text { cycles })=14 \%\end{array}$ & $\begin{array}{l}\text { OS }(\text { median })=11 \mathrm{mo}[4 \text { cycles }] \\
12 \mathrm{mo}[>4 \text { cycles }] \\
\text { PFS (median) }=8 \mathrm{mo}[4 \text { cycles }], \\
9 \mathrm{mo}[>4 \text { cycles }]\end{array}$ & $\begin{array}{l}\text { There is a lack of clinical benefit } \\
\text { by extending first-line platinum } \\
\text { combination treatment beyond } \\
\text { four cycles in selected patients. } \\
\text { This supports limiting the } \\
\text { number of cycles to four until the } \\
\text { superiority of a longer regimen is } \\
\text { identified in a randomized study. }\end{array}$ \\
\hline Sedef et al. & 2019 & Turkey & $\begin{array}{l}\text { No. of patients }=117 \\
\text { Age }(\text { median })=61 \\
\text { Gender }(\text { Male, } \%)=90 \%\end{array}$ & $\mathrm{CT}=100 \%$ & CT [PE/CE=100\%] & $\begin{array}{l}\text { OS }(\text { median })=13 \mathrm{mo} \\
\text { PFS }(\text { median })=8 \mathrm{mo}\end{array}$ & $\begin{array}{l}\text { Complete response and recurrent } \\
\text { free time were the prognostic } \\
\text { factors for ES SCLC patients in } \\
\text { our study }\end{array}$ \\
\hline Shirasawa et al. & 2019 & Japan & $\begin{array}{l}\text { No. of patients }=161 \\
\text { Age (median) }=72 \\
\text { Gender (Male, } \%)=85 \%\end{array}$ & $\mathrm{CT}=100 \%$ & Not available & $\begin{array}{l}\text { OS }(\text { median) w/ interstitial } \\
\text { pneumonia }=7.1 \mathrm{mo}, \mathrm{PFS} \\
\text { (median) w/out intertitial } \\
\text { pneumonia }=10.0 \mathrm{mo}\end{array}$ & $\begin{array}{l}\text { Systemic chemotherapy was } \\
\text { effective even in ED-SCLC } \\
\text { patients with IP }\end{array}$ \\
\hline Sukauichai et al. & 2019 & Thailand & $\begin{array}{l}\text { No. of patients }=35 \\
\text { Age }(\text { median })=61 \\
\text { Gender (Male, } \%)=83 \%\end{array}$ & $\begin{array}{l}\mathrm{CT}=80 \% \\
\mathrm{PCl}=3 \%\end{array}$ & $\begin{array}{l}\text { CT }[P E=51.4 \% ; \\
C E=28.7 \%]\end{array}$ & $\mathrm{OS}($ Median $)=5.9 \mathrm{mo}(\mathrm{ES})$ & $\begin{array}{l}\text { The OS of the limited stage SCLC } \\
\text { patients at our hospital was com- } \\
\text { parable to landmark studies. Most } \\
\text { received sequential chemoradia- } \\
\text { tion treatment }\end{array}$ \\
\hline \multicolumn{8}{|l|}{ Mixed treatment cohorts } \\
\hline Demeter et al. & 2003 & Canada & $\begin{array}{l}\text { No. of patients }=100 \\
\text { Gender }(\text { male })=75 \% \\
\text { Mean age, years }=61.9 \\
\text { Stage of disease }=33 \%[\text { LS }] \\
67 \%[\text { ES] }\end{array}$ & $\begin{array}{l}\mathrm{CT}=[\mathrm{LS}=86 \% ; \mathrm{ES}=64 \%] \\
\mathrm{CRT}=[\mathrm{LS}=83 \% \\
\mathrm{oES}=63 \%]\end{array}$ & Not available & OS (2yrs) $=22 \%$ [LS], 4\% [ES] & N/A \\
\hline Debevec et al. & 2005 & Slovenia & $\begin{array}{l}\text { No. of patients }=51 \\
\text { Stage of disease }=47 \%[\mathrm{LS}] \\
53 \%[\mathrm{ES}]\end{array}$ & Not available & Not available & $\begin{array}{l}\text { OS (1yr) }=45 \%[\text { LS], } 10 \%[\text { [ES] } \\
\text { OS (5yr) }=0 \%\end{array}$ & N/A \\
\hline Thammakumpee et al. & 2007 & Thailand & $\begin{array}{l}\text { No. of patients }=116 \\
\text { Mean age, years }=63 \\
(42-87) \\
\text { Gender (male) }=93 \% \\
\text { Stage of disease }=42 \% \text { [LS], } \\
58 \% \text { [ES] }\end{array}$ & $\begin{array}{l}\mathrm{CT}=26 \% \\
\mathrm{CRT}=28 \% \\
\mathrm{RT}=20 \% \\
\mathrm{BSC}=26 \%\end{array}$ & $\begin{array}{l}\mathrm{PE}=97 \% \text { (of } \mathrm{CT} / \mathrm{CRT} \\
\text { patients) }\end{array}$ & $\begin{array}{l}\mathrm{OS}(1 \mathrm{yr})=41 \%[\mathrm{LS}], 22.4 \% \\
{[\mathrm{ES}]} \\
\mathrm{OS}(2 \mathrm{yr})=12.5 \%[\mathrm{LS}], 3 \%[\mathrm{ES}]\end{array}$ & $\begin{array}{l}\text { Response to chemotherapy was } \\
\text { about } 50 \% \text { and } \\
\text { median survival was significantly } \\
\text { better than in } \\
\text { patients without chemotherapy for } \\
\text { both limited- and } \\
\text { extensive-stage patients. }\end{array}$ \\
\hline Sugiyama et al. & 2007 & Japan & $\begin{array}{l}\text { No. of patients }=94 \\
\text { Mean age, years }=66 \\
\text { Gender (male) }=83 \% \\
\text { Stage of disease }=44.7 \% \\
\text { [LS], } 55.3 \% \text { [ES] }\end{array}$ & $\mathrm{CT}=100 \%$ & $\begin{array}{l}\mathrm{PE}=60 \% \\
C E=21 \% \\
\text { Other }=19 \%\end{array}$ & Not available & N/A \\
\hline
\end{tabular}

Table S2 (continued) 


\begin{tabular}{|c|c|c|c|c|c|c|c|}
\hline Author & Year & Country & Patient characteristics & Treatment received & Regimen & Outcomes & Conclusion \\
\hline Duarte et al. & 2008 & Brazil & $\begin{array}{l}\text { No. of patients }=62 \\
\text { Mean age, years }=60.6 \\
\text { Gender }(\text { male })=71.2 \% \\
\text { Stage of disease }=59 \%[\text { LS]; } \\
41 \%[\text { ES] }\end{array}$ & $\mathrm{CT}=100 \%$ & $\begin{array}{l}\mathrm{PE}=69 \% \\
\mathrm{CE}=31 \%\end{array}$ & Not available & $\mathrm{N} / \mathrm{A}$ \\
\hline Li et al. & 2009 & China & $\begin{array}{l}\text { No. of patients }=126 \\
\text { Age group, years }=84[<70], \\
42[>70] \\
\text { Gender (male) }=69 \% \\
\text { Stage of disease }=49 \%[\mathrm{LS}], \\
51 \% \text { [ES] }\end{array}$ & $\mathrm{CT}=100 \%$ & $\begin{array}{l}\mathrm{PE}=65.8 \% \\
\mathrm{CAV}=34.2 \%\end{array}$ & $\begin{array}{l}\text { OS }(\text { median })=13 \mathrm{mo}[<70], \\
12 \mathrm{mo}[>70] \\
\mathrm{PFS}(\text { median })=8 \mathrm{mo}[<70], \\
7 \mathrm{mo}[>70]\end{array}$ & $\begin{array}{l}\text { SCLC patients } 70 \text { years or older } \\
\text { may tolerate and benefit from } \\
\text { standard chemotherapy regimens } \\
\text { (EP or CAV) with or without RT }\end{array}$ \\
\hline Noguchi et al. & 2010 & Japan & $\begin{array}{l}\text { No. of patients }=83 \\
\text { Age group, years }=38 \text { [70- } \\
79], 45[>80] \\
\text { Gender (Male, } \%)=68 \% \\
\text { Stage of disease }=70 \%[\text { [L] } \\
30 \% \text { [ES] }\end{array}$ & $\begin{array}{l}\mathrm{CT}=38.6 \% \\
\mathrm{CRT}=25.3 \% \\
\mathrm{RT}=4.8 \% \\
\mathrm{BSC}=31.3 \%\end{array}$ & Not available & $\begin{array}{l}\text { OS }(\text { median, ES) }=9.2 \mathrm{mo} \\
{[70-79], 10.3 \mathrm{mo}[>80]} \\
\text { OS }(2 \mathrm{yrs}, \mathrm{ES})=28 \%[70-79] \\
17 \%[>80]\end{array}$ & $\begin{array}{l}\text { Combination chemotherapy with } \\
\text { or without TRT is feasible for } \\
\text { patients aged } 80 \text { years with SCLC } \\
\text { with PS } 0 \text { to } 1 \text {, and even those } \\
\text { with PS } 2 \text { to } 3 \text { or moderate } \\
\text { comorbidities can benefit from } \\
\text { these treatments }\end{array}$ \\
\hline Devbhandari et al. & 2010 & UK & No. of patients $=67$ & & & $\begin{array}{l}\text { OS }(5 y r)=18 \%[\text { LS }=33 \%, \text { ES } \\
=3 \%]\end{array}$ & $\mathrm{N} / \mathrm{A}$ \\
\hline Garcia Prim et al. & 2010 & Spain & No. of patients $=98$ & & & $\begin{array}{l}\text { OS }(2 \mathrm{yr})=26.4 \% \\
\text { OS }(\text { median })=8.83 \mathrm{mo}[\text { LS] } \\
8.43 \mathrm{mo}[\mathrm{ES}]\end{array}$ & $\mathrm{N} / \mathrm{A}$ \\
\hline Nakao et al. & 2010 & Japan & $\begin{array}{l}\text { No. of patients }=30 \\
\text { Age group, years }=35 \% \\
{[<70], 55 \%[>70]} \\
\text { Stage of disease }=35 \%[\mathrm{LS}] \\
55 \%[\mathrm{ES}]\end{array}$ & CT $=100 \%$ & $\mathrm{AMR}=100 \%$ & $\begin{array}{l}\text { OS }(\text { median })=301 \text { days } \\
\text { PFS }(\text { median })=86 \text { days }\end{array}$ & $\mathrm{N} / \mathrm{A}$ \\
\hline Lebau et al. & 2011 & France & $\begin{array}{l}\text { No. of patients }=239 \\
\text { Mean age, years }=61 \\
(50-72) \\
\text { Gender (Male, } \%)=71 \% \\
\text { Stage of disease }=54.3 \% \\
{[\text { LS], } 45.7 \%[\text { ES] }}\end{array}$ & $\mathrm{CT}=100 \%$ & $\begin{array}{l}\mathrm{PCDE}=44 \% \\
\mathrm{PE}=32 \% \\
\text { Other }=24 \%\end{array}$ & $\begin{array}{l}\text { Complete response }=56 \% \\
{[\mathrm{PCDE}] ; 26 \%[\mathrm{PE}]} \\
\text { Objective response }=75 \% \\
{[\mathrm{PCDE}] ; \mathbf{4 0 \%}[\mathrm{PE}]}\end{array}$ & $\mathrm{N} / \mathrm{A}$ \\
\hline Hermes et al. & 2012 & Germany & $\begin{array}{l}\text { No. of SCLC patients }=397 \\
\text { Mean age, years }=63 \text { [LS- } \\
\text { SCLC] } 61 \text { [ES-SCLC] } \\
\text { Stage of disease }=39 \%[\text { LS]; } \\
61 \% \text { [ES] }\end{array}$ & $\begin{array}{l}\mathrm{CT}=28 \% \text { [LS-SCLC], } \\
95 \%[\mathrm{ES}-\mathrm{SCLC}] \\
\mathrm{CCRT}=72 \%[\mathrm{LS}-\mathrm{SCLC}] \\
5 \%[\mathrm{ES}-\mathrm{SCLC}] \\
\mathrm{PCI}=33 \%[\mathrm{LS}- \\
\mathrm{SCLC}], 22 \%[\mathrm{ES}-\mathrm{SCLC}]\end{array}$ & $\begin{array}{l}\mathrm{CE}=98.1 \%[\mathrm{LS}], \\
81.4 \%[\mathrm{ES}] \\
\mathrm{PE}=1.7 \%[\mathrm{LS}], 6.1 \% \\
{[\mathrm{ES}]} \\
\text { Other CT }=0.2 \%[\mathrm{LS}], \\
12.5 \%[\mathrm{ES}]\end{array}$ & $\begin{array}{l}\text { OS }(\text { median })=18.6 \mathrm{mo}[\mathrm{LS}], \\
8.7 \mathrm{mo}[\mathrm{ES}] \\
\mathrm{PFS}(\text { median })=7.2 \mathrm{mo}[\mathrm{LS}] \\
3.55 \mathrm{mo}[\mathrm{ES}]\end{array}$ & $\mathrm{N} / \mathrm{A}$ \\
\hline Fisher et al. & 2012 & Canada & $\begin{array}{l}\text { No. of patients }=171 \\
\text { Age group, years }=111 \text { [75- } \\
79], 60[>80] \\
\text { Gender (male) }=56.7 \% \\
\text { Stage of disease }=23 \%[\mathrm{LS}] \\
77 \%[\mathrm{ES}]\end{array}$ & $\mathrm{CT}=100 \%$ & $\begin{array}{l}\mathrm{PE}=47 \% \\
\mathrm{CE}=31 \% \\
\text { Oral etoposide }=21 \%\end{array}$ & $\begin{array}{l}\text { Outcomes presented as } \\
\text { univariable and multivariable } \\
\text { analyses }\end{array}$ & $\begin{array}{l}\text { Elderly patients who are able to } \\
\text { initiate chemotherapy are able } \\
\text { to tolerate treatment and receive } \\
\text { survival benefits from it }\end{array}$ \\
\hline
\end{tabular}

Table S2 (continued) 
Table S2 (continued)

\begin{tabular}{|c|c|c|c|c|c|c|c|}
\hline Author & Year & Country & Patient characteristics & Treatment received & Regimen & Outcomes & Conclusion \\
\hline Molina-Guillen et al. & 2012 & Spain & $\begin{array}{l}\text { No. of patients }=40 \\
\text { Mean age, years }=65.3 \\
\text { Gender }(\text { male })=90 \% \\
\text { Stage of disease }=37.5 \% \\
\text { [LS], } 62.5 \% \text { [ES] }\end{array}$ & $\mathrm{CT}=100 \%$ & $\begin{array}{l}\text { Platinum based (CE or } \\
P E)=100 \%\end{array}$ & $\mathrm{PFI}>6 \mathrm{mo}(\mathrm{ES}$ patients) $=28 \%$ & $\begin{array}{l}\text { Platinum based chemotherapy has } \\
\text { been shown to be more effective } \\
\text { in SCLC patients when they start } \\
\text { the treatment at LS disease than } \\
\text { ES. The } 73.3 \% \text { of the patients } \\
\text { diagnosed and treated at the LS } \\
\text { had a PFI longer than } 6 \text { months. } \\
\text { However, only } 28 \% \text { of the patients } \\
\text { who started the treatment at the } \\
\text { ES reached a PFI longer than } 6 \\
\text { months }\end{array}$ \\
\hline Fujitani et al. & 2013 & Japan & $\begin{array}{l}\text { No. of patients }=42 \\
\text { Mean age, years }=69 \\
\text { Gender }(\text { male })=85.7 \% \\
\text { Stage of disease }=26.2 \% \\
\text { [LS]; } 73.8 \% \text { [ES] }\end{array}$ & $\mathrm{CT}=100 \%$ & $\begin{array}{l}\mathrm{PE}=73.8 \% \\
\mathrm{PC}=26.2 \%\end{array}$ & $\begin{array}{l}\text { OS }(\text { median })=391 \text { days }[\mathrm{PE}] \\
\text { Not reached }[\mathrm{PC}]\end{array}$ & $\begin{array}{l}\text { Physicians preferred PE for older } \\
\text { patients as first-line therapy } \\
\text { Survival outcomes tended to be } \\
\text { better longer in the PC group }\end{array}$ \\
\hline Postmus et al. & 2013 & $\begin{array}{l}\text { Western } \\
\text { Europe, } \\
\text { Eastern } \\
\text { Europe and } \\
\text { Korea }\end{array}$ & $\begin{array}{l}\text { No. of patients }=507 \\
\text { Mean age, years }=65.4 \\
\text { Gender (male) }=73 \% \\
\text { Stage of disease }=34 \%[\mathrm{LS}] \text {, } \\
66 \%[\mathrm{ES}]\end{array}$ & $\begin{array}{l}\mathrm{CT}=59 \% \\
\mathrm{CRT}=67 \%[\mathrm{LS} \text { only }] \\
\mathrm{PCl}=26 \%[\mathrm{LS}=34 \%, \\
\mathrm{ED}=22 \%]\end{array}$ & $\begin{array}{l}\text { CT (first line) PE = } \\
90.7 \% ; \mathrm{CAV}=3.9 \% ; \\
\text { CYC =3.9\%; Other } \\
=2.5 \%]\end{array}$ & $\begin{array}{l}\text { OS }(\text { median })=10.6 \mathrm{mo} \text { [all } \\
\text { patients]; } 17.8 \mathrm{mo} \text { [LS]; } 8.7 \mathrm{mo} \\
\text { [ES] }\end{array}$ & $\begin{array}{l}\text { The combination of platinum and } \\
\text { etoposide remains first choice } \\
\text { of chemotherapy at first line and } \\
\text { often at relapse, followed by } \\
\text { topotecan starting from second- } \\
\text { line and beyond. }\end{array}$ \\
\hline Islam et al. & 2015 & Australia & $\begin{array}{l}\text { No. of patients }=41 \\
\text { Age group, years }=100 \% \\
(>70) \\
\text { Stage of disease }=22 \%[\mathrm{LS}] \text {, } \\
78 \%[\mathrm{ES}]\end{array}$ & $\begin{array}{l}\mathrm{CT}=78 \% \text { [All ES patients] } \\
\mathrm{CRT}=22 \% \text { [All LS } \\
\text { patients] } \\
\mathrm{PCl}=26 \%[\mathrm{LS}=34 \%, \\
\mathrm{ED}=22 \%]\end{array}$ & Not available & $\begin{array}{l}\text { OS }(\text { median })=355 \text { days }[\mathrm{LS}] \\
310 \text {, } \\
\text { PFS } \text { ( } \text { median) }=204 \text { days }[\mathrm{LS}] \\
155 \text { days }[\mathrm{ES}]\end{array}$ & $\begin{array}{l}\text { Elderly patients can be } \\
\text { treated with standard doublet } \\
\text { chemotherapy; however, dose } \\
\text { reductions are required for a } \\
\text { significant number of patients }\end{array}$ \\
\hline Li et al. & 2016 & China & $\begin{array}{l}\text { No. of patients }=77 \\
\text { Stage of disease }=42.7 \% \\
{[\text { LS], } 55.3 \%[E S]}\end{array}$ & $\begin{array}{l}\text { Untreated }=[\mathrm{LS}=32.4 \% ; \\
\mathrm{ES}=47.6 \%] \\
\mathrm{CT}=[\mathrm{LS}=38.2 \% ; \\
\mathrm{ES}=47.6 \%] \\
\mathrm{CRT}=[\mathrm{LS}=29.4 \% \\
\mathrm{ES}=2.4 \%]\end{array}$ & Not available & $\begin{array}{l}\text { OS }(\text { median })=14.23 \mathrm{mo}[\mathrm{LS}] \\
12.5 \mathrm{mo}[\mathrm{ES}]\end{array}$ & N/A \\
\hline Al Farsi et al. & 2017 & Canada & $\begin{array}{l}\text { No. of patients }=185 \\
\text { Mean age, years }=64 \\
\text { Gender (male) }=50 \% \\
\text { Stage of disease }=37 \%[\mathrm{LS}] \text {, } \\
63 \%[\mathrm{ES}]\end{array}$ & $\begin{array}{l}\mathrm{CT}=51 \% \\
\mathrm{CRT}=49 \% \\
\mathrm{PCl}=43.2 \%[\mathrm{LS}=64 \%, \\
\mathrm{ES}=39 \%]\end{array}$ & $\begin{array}{l}P E=53 \% \\
C E=47 \%\end{array}$ & $\begin{array}{l}\text { Incidence of relapse }=73 \% \\
\text { Time to relapse }=9.2 \mathrm{mo}[\mathrm{LS}= \\
14.3 \mathrm{mo}, \mathrm{ES}=7.5 \mathrm{mo}]\end{array}$ & $\begin{array}{l}<50 \% \text { of eligible SCLC patients } \\
\text { receive PCI. CNS relapse occurs } \\
\text { frequently and more commonly } \\
\text { in patients who do not receive } \\
\mathrm{PCl} \text {. Implementation of } \mathrm{PCl} \text { in } \\
\text { routine clinical practice appears to } \\
\text { influence patterns of recurrence. }\end{array}$ \\
\hline Silva et al. & 2017 & Portugal & $\begin{array}{l}\text { No. of patients }=144 \\
\text { Mean age, years }=65 \\
{[42-87]} \\
\text { Gender (male) }=79.9 \% \\
\text { Stage of disease }=25 \%[\mathrm{LS}] \text {, } \\
75 \% \text { [ES] }\end{array}$ & $\mathrm{CT}=100 \%$ & $P E=95.1 \%$ & $\begin{array}{l}\text { ORR }=64 \% \\
\text { OS }(\text { median) }=5.5 \mathrm{mo}\end{array}$ & $\begin{array}{l}\text { Clinical practice at the centre } \\
\text { represented that presented in the } \\
\text { current literature. New treatments } \\
\text { and predictive biomarkers for } \\
\text { SCLC are urgently needed }\end{array}$ \\
\hline
\end{tabular}

Table S2 (continued) 


\begin{tabular}{|c|c|c|c|c|c|c|c|}
\hline Author & Year & Country & Patient characteristics & Treatment received & Regimen & Outcomes & Conclusion \\
\hline Zhou et al. & 2017 & China & $\begin{array}{l}\text { No. of patients }=523 \\
\text { Median age, years }=59 \\
{[27-87]} \\
\text { Gender (male) }=79.3 \% \\
\text { Stage of disease }=26.8 \% \\
{[\mathrm{LS}] ; 73.2 \% \text { [ES] }}\end{array}$ & $\begin{array}{l}\mathrm{CT}=50.9 \%[\mathrm{LS}=39.3 \% \\
\mathrm{ES}=55.1 \%] \\
\mathrm{CRT}=49.1 \%[\mathrm{LS}=60.7 \\
\mathrm{ES}=44.9 \%] \\
\mathrm{PCl}=12.6 \%[\mathrm{LS}=23.6 \% \\
\mathrm{ES}=8.6 \%]\end{array}$ & $\begin{array}{l}\text { All patients received } \\
\text { either } P E, C E, C+\mid R I \\
\text { or } P+I R I\end{array}$ & $\begin{array}{l}\text { OS (median) }=21 \mathrm{mo}[\mathrm{LS}] \\
13 \mathrm{mo}[\mathrm{ES}] \\
\text { Other outcomes present as } \\
\text { univariable and multivariable } \\
\text { analyses }\end{array}$ & $\begin{array}{l}\text { Limited stage disease and } \\
\text { good response to initial therapy } \\
\text { predicted a better survival for } \\
\text { SCLC patients }\end{array}$ \\
\hline Aquin et al. & 2018 & Canada & $\begin{array}{l}\text { No. of patients }=531 \\
\text { Stage of disease }=30.2 \% \\
{[\mathrm{LS}], 69.8 \%[\mathrm{ES}]}\end{array}$ & $\mathrm{CT}=100 \%$ & $\begin{array}{l}\mathrm{PE}=73.8 \% \\
\mathrm{CE}=26.2 \%\end{array}$ & $\begin{array}{l}\text { OS (median) = } 322 \text { days }[\mathrm{PE}] \\
224 \text { days }[\mathrm{CE}] \\
\text { Other outcomes present as } \\
\text { univariable and multivariable } \\
\text { analyses }\end{array}$ & $\begin{array}{l}\text { Carboplatin appears to be an } \\
\text { equally effective treatment option } \\
\text { for SCLC, facilitating equivalent } \\
\text { survival while avoiding toxicity }\end{array}$ \\
\hline El Benna et al. & 2018 & Tunisia & $\begin{array}{l}\text { No. of patient } s=60 \\
\text { Mean age, years }=61[ \pm 6.5] \\
\text { Gender }(\text { male })=95 \% \\
\text { Stage of disease }=33.3 \% \\
{[\text { LS], } 66.7 \%[E S]}\end{array}$ & $\mathrm{CT}=100 \%$ & $\begin{array}{l}\text { CE/PE = 85\%; Other } \\
=15 \%\end{array}$ & N/A & $\begin{array}{l}\text { Patients with SCLC are highly } \\
\text { responsive to chemotherapy and } \\
\text { radiation therapy. Long-term } \\
\text { prognosis remains poor, with } \\
\text { relapse and disease recurrence } \\
\text { occurring in almost all cases }\end{array}$ \\
\hline Hong et al. & 2018 & China & $\begin{array}{l}\text { No. of patients }=999 \\
\text { Age group, years }=61.3 \% \\
{[<60], 38.7 \%[>60]} \\
\text { Gender (male) }=69.3 \% \\
\text { Stage of disease }=59.1 \% \\
{[\text { LS], } 40.9 \%[\text { [ES] }}\end{array}$ & $\begin{array}{l}\text { Surgery }+ \text { CRT }=5.9 \%[\text { LS } \\
=9.9 \% ;] \\
\text { CT }=55.1 \%[\text { LS }=52.5 \%, \\
\text { ES }=56.8 \%] \\
\text { CRT }=33.5 \%[\text { LS }=33.2, \\
\text { ES }=32.8 \%]\end{array}$ & $\begin{array}{l}\mathrm{PE}=89.3 \%[\mathrm{LS}= \\
88.8 \%, \mathrm{ES}=90.1 \%] \\
\text { Non-PE }=10.7 \%[\mathrm{LS} \\
=11.2 \%, \mathrm{ES}=9.9 \%]\end{array}$ & $\begin{array}{l}\mathrm{OS}(1 \mathrm{yr})=50.5 \%[\mathrm{LS}], 32.2 \% \\
{[\mathrm{ES}]} \\
\mathrm{OS}(2 \mathrm{yr})=14.5 \%[\mathrm{LS}], 8.7 \% \\
{[\mathrm{ES}]} \\
\mathrm{OS}(3 \mathrm{yr})=3.1 \%[\mathrm{LS}], 2.6 \% \\
{[\mathrm{ES}]}\end{array}$ & $\begin{array}{l}\text { Several factors, including } \\
\text { patient, tumour, and treatment } \\
\text { characteristics and serum LDH } \\
\text { levels are independent prognostic } \\
\text { factors for OS and PFS in Chinese } \\
\text { patients with SCLC }\end{array}$ \\
\hline Lattuca-Truc et al. & 2018 & France & $\begin{array}{l}\text { No. of patients }=529 \\
\text { Median age, years }=64 \\
\text { Gender (male) }=77 \% \\
\text { Stage of disease }=42 \%[\text { LS], } \\
58 \%[\text { ES] }\end{array}$ & $\begin{array}{l}\mathrm{CT}=35 \% \\
\mathrm{CRT}=65 \% \\
\mathrm{PCI}=[1997-09=26 \%, \\
2009-19=32 \%]\end{array}$ & $\begin{array}{l}\text { Platinum based (CE or } \\
P E)=96 \%\end{array}$ & $\begin{array}{l}\text { Median OS = 12mo }[1997- \\
09=13 \mathrm{mo}, 2009-17=11 \mathrm{mo}]\end{array}$ & $\begin{array}{l}\text { Since } 1997 \text { there was no } \\
\text { improvement in survival nor } \\
\text { response rate to chemotherapy } \\
\text { in SCLC patients. There is } \\
\text { a desperate need for new } \\
\text { approaches in this setting }\end{array}$ \\
\hline Saber et al. & 2018 & Egypt & No. of patients $=24$ & $\mathrm{CT}=84 \%$ & $\mathrm{PE} / \mathrm{CE}=100 \%$ & $\begin{array}{l}\text { OS }(\text { median })=7.7 \mathrm{mo} \\
\text { PFS }(\text { median })=5.4 \mathrm{mo}\end{array}$ & N/A \\
\hline $\begin{array}{l}\text { Cramer-Van Der Welle } \\
\text { et al. }\end{array}$ & 2019 & Netherlands & $\begin{array}{l}\text { No. of patients }=501 \\
\text { Age }(\text { mean })=66 \\
\text { Gender }(\text { Male } \%)=67 \% \\
\text { Stage of disease }=100 \%[\text { ES }]\end{array}$ & $\mathrm{CT}=100 \%$ & Not available & $\mathrm{OS}($ median $)=7.4 \mathrm{mo}$ & $\begin{array}{l}\text { After first line systemic treatment } \\
\text { in ED SCLC the fraction of } \\
\text { patients receiving subsequent } \\
\text { lines of treatment is rapidly } \\
\text { decreasing }\end{array}$ \\
\hline Incanc et al. & 2019 & Turkey & $\begin{array}{l}\text { No. of patients }=177 \\
\text { Age }(\text { mean })=56 \\
\text { Gender }(\text { Male, } \%)=91 \% \\
\text { Stage of disease }=41 \%[\mathrm{LS}] \\
59 \%[\text { ES] }\end{array}$ & $\mathrm{CT}=100 \%$ & $P E=100 \%$ & Not available & $\begin{array}{l}\text { We evaluated the relationship be- } \\
\text { tween NLR and SCLC, and found } \\
\text { that NLR is a potential prognostic } \\
\text { serum marker in patients with } \\
\text { SCLC }\end{array}$ \\
\hline \multicolumn{8}{|c|}{ Chemotherapy/Chemoradiotherapy $2^{\text {nd }} / 3^{\text {rd }}$ line - Extensive stage } \\
\hline Asai et al. & 2012 & Japan & $\begin{array}{l}\text { No. of patients }=36 \text { [second- } \\
\text { line }=12 \%, \text { third-line }=88 \%] \\
\text { Mean age, years }=69[47-83] \\
\text { Gender (male) }=89 \% \\
\text { Prior therapies }[\mathrm{CE}=62 \%, \\
P E=25 \%, \text { other }=13 \%]\end{array}$ & CT & $\mathrm{AMR}=100 \%$ & $\begin{array}{l}\text { OS }(\text { median })=5.1 \mathrm{mo} \\
\mathrm{PFS}(\text { median })=2.9 \mathrm{mo}\end{array}$ & $\begin{array}{l}\text { AMR has the potential to be } \\
\text { effective tool for the treatment of } \\
\text { elderly patients (i.e. }>70 \text { years) } \\
\text { with R/R SCLC }\end{array}$ \\
\hline
\end{tabular}

Table S2 (continued) 


\begin{tabular}{|c|c|c|c|c|c|c|c|}
\hline Author & Year & Country & Patient characteristics & Treatment received & Regimen & Outcomes & Conclusion \\
\hline Inomata et al. & 2014 & Japan & $\begin{array}{l}\text { No. of patients }=19 \\
\text { Mean age, years }=68 \\
{[47-78]} \\
\text { Gender (male) }=94.7 \% \\
\text { Prior therapies [first-line } \\
\text { platinum }=100 \% \text {; second- } \\
\text { line re-challenged platinum = } \\
57.1 \% \text { ] }\end{array}$ & CT & $\begin{array}{l}\text { Platinum doublet }= \\
15.7 \% \\
\text { AMR }=47.4 \% \\
\text { TOP }=21 \% \\
\text { IRI }=10.4 \% \\
\text { PTX }=5.2 \%\end{array}$ & $\mathrm{OS}($ median $)=8.5 \mathrm{mo}$ & $\begin{array}{l}\text { Numerous prognostic factors } \\
\text { identified for improved OS in third- } \\
\text { line SCLC }\end{array}$ \\
\hline Morise et al. & 2014 & Japan & $\begin{array}{l}\text { No. of patients }=57 \\
\text { Mean age, years }=70 \\
{[51-83]} \\
\text { Gender }(\text { male })=91 \% \\
\text { Prior therapies }[\mathrm{PE}=47 \% \text {, } \\
\mathrm{CE}=46 \%, \mathrm{RDT}=42, \mathrm{PCl}= \\
23 \%]\end{array}$ & CT & $|\mathrm{R}|=100 \%$ & $\begin{array}{l}\text { ORR }=32 \% \\
\text { OS }(\text { median })=5.3 \mathrm{mo} \\
\text { PFS }(\text { median })=2.9 \mathrm{mo}\end{array}$ & $\begin{array}{l}\text { Low dose IRI has the potential to } \\
\text { be an effective option for third-line } \\
\text { SCLC with favourable toxicity }\end{array}$ \\
\hline Murakami et al. & 2015 & Japan & $\begin{array}{l}\text { No. of patients }=39 \\
\text { Mean age, years }=68 \\
\text { Gender (male) }=87.2 \%\end{array}$ & CT & $\begin{array}{l}\text { Re-challenge (existing } \\
\text { platinum) }=33.3 \% \\
\text { AMR }=51.2 \% \\
\text { Other }=15.5 \%\end{array}$ & $\begin{array}{l}\text { OS } \text { (median) }=44.2 \mathrm{mo} \text { [re- } \\
\text { challenge], 20.9mo [AMR] } \\
\text { PFS (median) = 8.2mo [re- } \\
\text { challenge], 4.9mo [AMR] }\end{array}$ & $\begin{array}{l}\text { Platinum re-challenge therapy } \\
\text { provide better outcomes than } \\
\text { single agent chemotherapy for } \\
\text { relapsed SCLC }\end{array}$ \\
\hline Aktas et al. & 2016 & Turkey & $\begin{array}{l}\text { No. of ES-SCLC patients = } \\
255 \\
\text { No. of ES-SCLC patients } \\
\text { receiving second-line } \\
\text { therapy }=117 \text { [primary } \\
\text { resistant }=17 \% \text {, platinum } \\
\text { sensitive }=83 \% \text { ] } \\
\text { No. of ES-SCLC patients } \\
\text { receiving third-line therapy = } \\
25 \text { [primary resistant }=12 \%, \\
\text { platinum sensitive }=88 \% \text { ] } \\
\text { Mean age, years }=57[39-74] \\
\text { Gender }(\text { Male, } \%)=92 \%\end{array}$ & $\begin{array}{l}\mathrm{CT} \text { (second-line and third- } \\
\text { line regimen provided) }\end{array}$ & $\begin{array}{l}\mathrm{IRI} / \mathrm{TOP}=44 \% \\
\mathrm{TOP} / \mathrm{IRI}=56 \%\end{array}$ & $\begin{array}{l}\text { OS }(\text { median })=18 \mathrm{mo}[\mathrm{IRI} / \mathrm{TOP}] \\
14 \mathrm{mo}[\mathrm{TOP} / \mathrm{IRI}] \\
\mathrm{PFS}(\text { median })=14 \mathrm{wks}[\mathrm{IRI} / \\
\text { TOP], } 12 \mathrm{wks}[\mathrm{TOP} / \mathrm{RI}]\end{array}$ & $\begin{array}{l}\text { Sequential monotherapy of TOP } \\
\text { and IRI provide a considerable } \\
\text { contribution to OS but sequencing } \\
\text { of treatment provides similar } \\
\text { outcomes }\end{array}$ \\
\hline Granados et al. & 2017 & Spain & $\begin{array}{l}\text { No. of patients }=83 \\
\text { Mean age, years }=58 \\
{[43-81]} \\
\text { Gender }(\text { male) }=83.2 \% \\
\text { Prior therapies }[\mathrm{CE}=38.7 \% \text {, } \\
\mathrm{PE}=60.3 \%]\end{array}$ & CT & $\mathrm{PTX}+\mathrm{GCB}=100 \%$ & $\begin{array}{l}\text { OS }(\text { median })=172 \text { days } \\
\text { PFS (median) }=148 \text { days } \\
\text { Treatment cessation (toxicity) } \\
=14.4 \%\end{array}$ & $\begin{array}{l}\mathrm{PTX}+\mathrm{GCB} \text { is a well-tolerated } \\
\text { regimen for relapsed SCLC and } \\
\text { contributes to OS and PFS }\end{array}$ \\
\hline Itotani et al. & 2017 & Japan & $\begin{array}{l}\text { No. of patients }=21 \\
\text { Mean age, years }=70[ \pm 5.6] \\
\text { Gender }(\text { male })=85.7 \% \\
\text { ILD }=100 \%\end{array}$ & CT & $\mathrm{C}+\mathrm{PTX}=100 \%$ & $\begin{array}{l}\text { OS }(\text { median })=7.1 \mathrm{mo} \\
\text { PFS }(\text { median })=3.5 \mathrm{mo}\end{array}$ & $\begin{array}{l}\text { In previously treated SCLC } \\
\text { patients with ILD who had } \\
\text { received more than one cytotoxic } \\
\text { chemotherapy regimen, C+PTX is } \\
\text { an effective treatment regimen }\end{array}$ \\
\hline Minemura et al. & 2017 & Japan & $\begin{array}{l}\text { No. of patients }=86 \\
\text { Mean age, years }=74 \\
\text { [70-84] } \\
\text { Stage of disease }=48 \% \\
\text { [sensitive relapse], } 52 \% \\
\text { [refractory relapse] }\end{array}$ & CT & $A M R=100 \%$ & $\begin{array}{l}\text { OS }(\text { median })=7.6 \mathrm{mo} \text { [sensitive } \\
\text { relapse], 5.5mo [refractory } \\
\text { relapse] } \\
\mathrm{PFS}(\mathrm{median})=4 \mathrm{mo} \text { [sensitive } \\
\text { relapse], } 2.7 \mathrm{mo} \text { [refractory } \\
\text { relapse] }\end{array}$ & $\begin{array}{l}\text { Amrubicin demonstrated anti- } \\
\text { tumour activity in both sensitive } \\
\text { and refractory relapsed SCLC } \\
\text { patients }\end{array}$ \\
\hline
\end{tabular}

Table S2 (continued) 
Table S2 (continued)

\begin{tabular}{|c|c|c|c|c|c|c|c|}
\hline Author & Year & Country & Patient characteristics & Treatment received & Regimen & Outcomes & Conclusion \\
\hline Yu et al. & 2017 & Japan & No. of patients $=54$ & CT & $\begin{array}{l}\text { IRO+NED = 63\% } \\
\text { IRO+P = 37\% }\end{array}$ & $\begin{array}{l}\text { OS (median) = 62wks } \\
\text { (IRO+NED), 58wks (IRO+P) } \\
\text { PFS (median) = 23wks } \\
\text { (IRO+NED), 19wks (IRO+P) }\end{array}$ & $\begin{array}{l}\text { Irinotecan plus platinum is } \\
\text { effective and tolerable for } \\
\text { refractory and relapsed small cell } \\
\text { lung cancer }\end{array}$ \\
\hline Wang et al. & 2017 & China & No. of patients $=82$ & CT & $\begin{array}{l}\mathrm{IRO}+\mathrm{PE}=54 \% \\
\mathrm{TOP}=46 \%\end{array}$ & $\begin{array}{l}\text { OS }(\text { median })=16.3(\text { IRO+PE }) \\
10.1 \mathrm{mo}(\mathrm{TOP}) \\
\mathrm{PFS}(\text { median })=6.2(\text { IRO+NED }), \\
4.1(\mathrm{IRO}+\mathrm{P})\end{array}$ & $\begin{array}{l}\text { Combined chemotherapy with } \\
\text { PEI is not inferior to topotecan } \\
\text { monotherapy at second-line } \\
\text { treatment }\end{array}$ \\
\hline Zhang et al. & 2018 & China & No. of patients $=78$ & CT & $\begin{array}{l}\mathrm{P}+\mathrm{E}+\mathrm{IRO}=15.7 \% \\
\mathrm{TOP}=47.4 \%\end{array}$ & $\begin{array}{l}\text { OS (median) }=16.3 \mathrm{mo} \\
{[\mathrm{PE}+\mathrm{IRO}] 13.1 \mathrm{mo}[66]}\end{array}$ & $\begin{array}{l}\text { Combination chemotherapy with } \\
\mathrm{C}+\mathrm{E}+\mathrm{IRO} \text { could be considered as } \\
\text { a second-line treatment option in } \\
\text { patients with relapsed sensitive } \\
\text { SCLC }\end{array}$ \\
\hline von Eiff et al. & 2018 & Germany & $\begin{array}{l}\text { No. of patients }=185 \\
\text { Mean age, years }=64 \\
\text { Gender }(\text { male })=64.3 \% \\
\text { Prior therapies }=100 \%[\mathrm{CE} / \\
\text { PE] }\end{array}$ & CT & PTX $=100 \%$ & $\begin{array}{l}\text { OS }(\text { median })=100 \text { days } \\
\text { PFS }(\text { median })=48 \text { days }\end{array}$ & $\begin{array}{l}\text { Patients in good condition } \\
\text { and without cerebral/hepatic } \\
\text { metastases benefit from PTX } \\
\text { therapy in relapsed SCLC }\end{array}$ \\
\hline Saijo et al. & 2019 & Japan & $\begin{array}{l}\text { No. of patients }=17 \\
\text { Gender }(\text { Male, } \%)=71.1 \%\end{array}$ & CT & $\mathrm{PTX}=44.7 \%$ & $\begin{array}{l}\mathrm{OS}(\text { median })=2.7 \mathrm{mo} ; \mathrm{PFS} \\
(\text { median })=3.6 \mathrm{mo}\end{array}$ & $\begin{array}{l}\text { Although PTX-containing } \\
\text { regimens demonstrated promising } \\
\text { anti-tumor activity against } \\
\text { relapsed SCLC with IIPs, the } \\
\text { survival benefit was limited } \\
\text { because of the high incidence } \\
\text { of PTX-related AE of IIPs and } \\
\text { treatment-related death }\end{array}$ \\
\hline Moharana et al. & 2019 & India & No. of patients $=12$ & CT & $\mathrm{PTX} / \mathrm{IRI}=100 \%$ & PFS (median) 1.5mo & $\begin{array}{l}\text { Weekly Paclitaxel in } 2 \text { nd line may } \\
\text { have favourable toxicity profile } \\
\text { and response rate comparable to } \\
\text { Irinotecan or Temozolomide }\end{array}$ \\
\hline Moser & 2019 & Israel & $\begin{array}{l}\text { No. of patients }=235 \\
\text { Age }(\text { median })=64 \\
\text { Gender (Male, } \%)=61 \% \\
\text { Prior therapies }=100 \%[\mathrm{PE}]\end{array}$ & CT & Not available & $\mathrm{OS}($ median $)=11.8 \mathrm{~m}$ & $\begin{array}{l}\text { Overall survival for SCLC patients } \\
\text { in a real world setting was found } \\
\text { to be similar to those reported in } \\
\text { clinical trials }\end{array}$ \\
\hline Sugiyama et al. & 2019 & Japan & $\begin{array}{l}\text { No. of patients }=31 \\
\text { Age }(\text { mean })=69 \\
\text { Gender (Male, } \%)=85 \%\end{array}$ & CT & PTX $=100 \%$ & $\begin{array}{l}\mathrm{OS}(\text { median })=4.4 \mathrm{mo}, \mathrm{PFS} \\
(\text { median })=2.2 \mathrm{mo}\end{array}$ & $\begin{array}{l}\text { PTX monotherapy showed moder- } \\
\text { ate efficacy with acceptable toxic- } \\
\text { ity in heavily treated patients with } \\
\text { R/R SCLC patients }\end{array}$ \\
\hline Sone et al. & 2018 & Japan & $\begin{array}{l}\text { No. of patients }=31 \\
\text { Mean age, years }=72(>65) \\
\text { Gender (male) }=83.9 \%\end{array}$ & $\mathrm{CT}=100 \%$ & CT [AMR=100\%] & $\begin{array}{l}\mathrm{OS}(\text { median })=11.6 \mathrm{mo} \\
\mathrm{PFS}(\text { median })=5.4 \mathrm{mo}\end{array}$ & $\begin{array}{l}\text { AMR has the potential to be } \\
\text { an effective regimen for elderly } \\
\text { patients with ES-SCLC, in } \\
\text { particular for patients with } \\
\text { relapsed SCLC }\end{array}$ \\
\hline Zhao et al. & 2019 & China & $\begin{array}{l}\text { No. of patients }=116 \\
\text { Age } \leq 65(180),>65(92) \\
\text { Gender (Male, } \%)=84.9 \%\end{array}$ & CT & TOP/PTX/DTX=100\% & $\begin{array}{l}\text { OS (median) IRI = 595d; TOP } \\
=154 \mathrm{~d} ; \text { PTX = 168.5d; DTX = } \\
\text { 184d; PFS (median) IRI = 91d; } \\
\text { TOP = 74.5d; PTX = 81d; DTX } \\
=50 \mathrm{~d}\end{array}$ & $\begin{array}{l}\text { Second-line chemotherapy with } \\
\text { TPT in SCLC patients may provide } \\
\text { better overall survival benefits }\end{array}$ \\
\hline
\end{tabular}

Table S2 (continued) 
Table S2 (continued)

\begin{tabular}{|c|c|c|c|c|c|c|c|}
\hline Author & Year & Country & Patient characteristics & Treatment received & Regimen & Outcomes & Conclusion \\
\hline \multicolumn{8}{|c|}{ Prophylactic Cranial Irradiation (PCI) } \\
\hline Stanic et al. & 2010 & Slovenia & $\begin{array}{l}\text { No. of patients }=356 \\
\text { Gender }(\text { male })=75 \% \\
\text { Mean age, years }=61.9 \\
\text { Stage of disease }=48 \%[\text { LS], } \\
52 \%[\text { ES] }\end{array}$ & $\begin{array}{l}\mathrm{PCI}=6 \% \\
\mathrm{CT}=41 \% \\
\mathrm{CRT}=48.5 \%\end{array}$ & N/A & $\begin{array}{l}\text { OS }(\text { median })=21.9 \mathrm{mo}[\mathrm{PCl}] \\
12.13 \mathrm{mo}[\mathrm{no} \mathrm{PCl}] \\
\text { Brain metastases }=25 \%\end{array}$ & $\begin{array}{l}\text { Increased median survival time } \\
\text { and decreased incidence for brain } \\
\text { metastases in patients with PCI. } \\
\text { Recommendation to perform PCl } \\
\text { in patients with LS disease and } \\
\text { good performance status }\end{array}$ \\
\hline Nakahara et al. & 2012 & Japan & $\begin{array}{l}\text { No. of patients }=17 \\
\text { Mean age, years }=66 \\
{[52-78]}\end{array}$ & $\mathrm{PCl}=100 \%$ & N/A & $\begin{array}{l}\text { Brain metastases }(\%)=35 \% \\
\text { Dementia (incidence) }=29 \% \\
\text { Gait disturbance (incidence) = } \\
18 \%\end{array}$ & $\begin{array}{l}\text { Impact of PCl on neurocognitive } \\
\text { functioning is significant and } \\
\text { should be weighed against } \\
\text { survival benefits, especially in } \\
\text { older patients }\end{array}$ \\
\hline Ramlov et al. & 2012 & Denmark & $\begin{array}{l}\text { No. of patients }=118 \\
\text { Gender }(\text { male })=43 \% \\
\text { Stage of disease }=62.7 \% \\
{[\text { LS], } 37.3 \%[E S]}\end{array}$ & $\begin{array}{l}\mathrm{PCl}=100 \% \\
\text { Surgery }=6 \% \\
\mathrm{CRT}=53 \% \\
\text { Palliative CT/CRT }=41 \%\end{array}$ & N/A & $\begin{array}{l}\text { OS }(\text { median })=24 \mathrm{mo}[\mathrm{LS}] \\
12 \mathrm{mo}[\mathrm{ES}] \\
\text { Cerebral reoccurrence }(\%)= \\
17 \%\end{array}$ & $\begin{array}{l}\mathrm{PCl} \text { lowers likelihood of } \\
\text { developing brain metastases in } \\
\text { SCLC }\end{array}$ \\
\hline Ozawa et al. & 2014 & Japan & $\begin{array}{l}\text { No. of patients }=124 \\
\text { Mean age, years }=65 \\
\text { Stage of disease }=100 \% \\
{[\text { LS] }}\end{array}$ & $\mathrm{PCl}=23.3 \%$ & $\mathrm{~N} / \mathrm{A}$ & $\begin{array}{l}\text { OS }(\text { median })=25.5 \mathrm{mo}[\mathrm{PCl}] \\
34.5 \mathrm{mo}[\mathrm{no} \mathrm{PCl}] \\
\text { Brain metastases }(2 \mathrm{yrs})= \\
45.5 \%[\mathrm{PCl}] 29.9 \%[\mathrm{no} \mathrm{PCl}]\end{array}$ & $\begin{array}{l}\mathrm{PCl} \text { does not benefit patients } \\
\text { with LS-SCLC in conjunction with } \\
\text { periodical brain screening and } \\
\text { thoracic radiotherapy }\end{array}$ \\
\hline Zhu et al. & 2014 & China & $\begin{array}{l}\text { No. of patients }=193 \\
\text { Mean age, years }=56 \\
\text { Stage of disease }=100 \% \\
\text { [LS] }\end{array}$ & $\begin{array}{l}\mathrm{PCl}=34.7 \% \\
\text { Surgery }=100 \%\end{array}$ & N/A & $\begin{array}{l}\text { OS }(2 \mathrm{y})=92.5 \%[\mathrm{PCl}] 63.2 \% \\
{[\text { non-PCl] }} \\
\text { OS }(5 \mathrm{yr})=54.9 \%[\mathrm{PCl}], 47.8 \% \\
\text { [non-PCl] } \\
\text { Brain metastases free survival } \\
(2 \mathrm{yrs})=96.8 \%[\mathrm{PCl}], 79.4 \% \\
\text { [non-PCl] }\end{array}$ & $\begin{array}{l}\text { PCI improves survival and lowers } \\
\text { likelihood of developing brain } \\
\text { metastases in patients with } \\
\text { surgically resected SCLC }\end{array}$ \\
\hline Bang et al. & 2015 & Canada & $\begin{array}{l}\text { No. of patients }=399 \\
\text { Stage of disease }=100 \% \\
{[E S]}\end{array}$ & $\begin{array}{l}\mathrm{PCl}=17.3 \% \text { (uptake } \\
\text { pre-2008=24.2\%; post- } \\
2008=57.6 \%)\end{array}$ & $\mathrm{N} / \mathrm{A}$ & $\begin{array}{l}\text { OS }(\text { median })=14 \mathrm{mo}[\mathrm{PCl}] \\
8.2 \mathrm{mo}[\mathrm{No} \mathrm{PCl}] \\
\text { Brain metastases }(2 \mathrm{yrs})= \\
40.6 \%[\mathrm{PCl}] 43.8 \%[\mathrm{No} \mathrm{PCl}]\end{array}$ & $\begin{array}{l}\mathrm{PCl} \text { in the setting of at least partial } \\
\text { response to chemotherapy was } \\
\text { found to have a survival benefit } \\
\text { and prolongation of time to brain } \\
\text { metastasis }\end{array}$ \\
\hline Zeng et al. & 2016 & China & $\begin{array}{l}\text { No. of patients }=175 \\
\text { Mean age, years }=55 \\
\text { Gender }(\text { male })=73.7 \% \\
\text { Stage of disease }=88.6 \% \\
{[\text { LS], } 11.4 \% \text { [ES] }}\end{array}$ & $\mathrm{PCl}=100 \%$ & $\mathrm{~N} / \mathrm{A}$ & $\begin{array}{l}\text { OS }(5 y r)=48 \% \\
\text { Brain metastases free survival } \\
(2 \mathrm{yrs})=54.9 \%[\mathrm{PCl}]\end{array}$ & \\
\hline Qiu et al. & 2016 & China & $\begin{array}{l}\text { No. of patients }=399 \\
\text { Mean age, years }=55 \\
(25-79) \\
\text { Gender (male) }=81 \% \\
\text { Stage of disease }=100 \% \\
{[\text { LS] }}\end{array}$ & $\begin{array}{l}\mathrm{PCl}=46.4 \% \\
\mathrm{CRT}=100 \%\end{array}$ & N/A & $\begin{array}{l}\text { OS (median) }=32.6 \mathrm{mo} \text { [Early } \\
\mathrm{PCl}], 40.9 \text { [Late PCl], } 21.5 \mathrm{mo} \\
\text { [No PCl] } \\
\text { Brain metastases (2yrs) }=13 \% \\
\text { [PCl], } 42 \% \text { [No PCl] }\end{array}$ & $\begin{array}{l}\mathrm{PCl} \text { significantly decreased the } \\
\text { incidence of brain metastases } \\
\text { and improved the overall survival } \\
\text { rate in patients with LS-SCLC. } \\
\text { Early PCl administered within } \\
6 \text { months of the start of first- } \\
\text { line chemotherapy was as } \\
\text { effective as late } \mathrm{PCI} \text { (PCI that was } \\
\text { administered } 6 \text { months later) }\end{array}$ \\
\hline
\end{tabular}

Table S2 (continued) 
Table S2 (continued)

\begin{tabular}{|c|c|c|c|c|c|c|c|}
\hline Author & Year & Country & Patient characteristics & Treatment received & Regimen & Outcomes & Conclusion \\
\hline Matutino et al. & 2017 & Brazil & $\begin{array}{l}\text { No. of patients }=46 \\
\text { Stage of disease }=100 \% \\
{[E S]}\end{array}$ & $\begin{array}{l}\mathrm{PCl}=35 \% \\
\mathrm{CT} \text { (platinum) }=100 \%\end{array}$ & $\mathrm{~N} / \mathrm{A}$ & $\begin{array}{l}\text { OS }(\text { median })=20.94 \mathrm{mo}[\mathrm{PCl}] \\
11.05 \text { mo }[\mathrm{No} \mathrm{PCl}] \\
\mathrm{PFS}(\text { median })=10.32 \mathrm{mo} \\
{[\mathrm{PCl}], 7.66 \mathrm{mo}[\mathrm{No} \mathrm{PCl}]} \\
\text { Brain metastases }(2 \mathrm{yrs})=19 \% \\
{[\mathrm{PCl}], 53 \%[\text { No PCl] }}\end{array}$ & $\begin{array}{l}\text { Careful patient selection for } \\
\mathrm{PCl} \text { can improve not only brain } \\
\text { metastases but also patient } \\
\text { survival. }\end{array}$ \\
\hline Mamesaya et al. & 2017 & Japan & $\begin{array}{l}\text { No. of patients }=79 \\
\text { Mean age, years }=67(34-83) \\
\text { Gender }(\text { male })=68 \% \\
\text { Stage of disease }=100 \% \\
\text { [LS] }\end{array}$ & $\begin{array}{l}\mathrm{PCI}=73.4 \%[\mathrm{CR}=26.5 \% \\
\mathrm{PR}=46.8 \%] \\
\mathrm{CRT}=100 \%\end{array}$ & N/A & 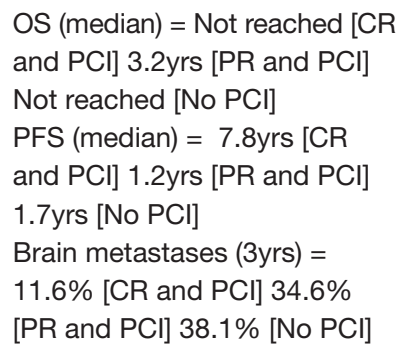 & $\begin{array}{l}\text { PCI may not add clinical benefit } \\
\text { to LS-SCLC patients who did not } \\
\text { achieve CR after } \\
\text { initial therapy if absence of bone } \\
\text { metastases could be confirmed } \\
\text { by MRI immediately before PCl } \\
\text { administration }\end{array}$ \\
\hline Soon et al. & 2018 & Singapore & $\begin{array}{l}\text { No. of patients }=71 \\
\text { Gender }(\text { male })=83.6 \% \\
\text { Stage of disease }=100 \% \\
{[E S]}\end{array}$ & $\begin{array}{l}\mathrm{PCl}=22.5 \% \\
\mathrm{CT}=77.5 \% \text { [Platinum } \\
\text { based }=93 \%] \\
\mathrm{CRT}=22.5 \%\end{array}$ & N/A & $\begin{array}{l}\text { Outcomes presented as } \\
\text { univariable and multivariable } \\
\text { analyses }\end{array}$ & $\begin{array}{l}\text { Increased utilisation of PCI was } \\
\text { observed after publication of } \\
\text { the EORTC trial (2006) and PCI } \\
\text { was associated with improved } \\
\text { survival in patients with at least } \\
\text { stable disease following initial } \\
\text { chemotherapy }\end{array}$ \\
\hline Srivastava et al. & 2018 & New Zealand & $\begin{array}{l}\text { No. of patients }=245 \\
\text { Gender }(\text { male })=45 \% \\
\text { Mean age, years }=63 \\
\text { Stage of disease }=100 \% \\
{[E S]}\end{array}$ & $\begin{array}{l}\mathrm{PCl}=19.5 \% \\
\mathrm{CT}=89.4 \% \\
\mathrm{CRT}=11.6 \%\end{array}$ & $\mathrm{~N} / \mathrm{A}$ & $\begin{array}{l}\text { OS }(\text { median })=14.3 \mathrm{mo}[\mathrm{PCl}] \\
6.3 \mathrm{mo}[\mathrm{No} \mathrm{PCl}]\end{array}$ & $\begin{array}{l}\text { Patients who received PCI had } \\
\text { improved survival, although this } \\
\text { positive association is no longer } \\
\text { observed after } \\
\text { stratifying patient according to } \\
\text { treatment (i.e. chemotherapy and } \\
\text { radiotherapy) characteristic }\end{array}$ \\
\hline Boskovic et al. & 2019 & Serbia & No. of patients $=200$ & $\mathrm{PCl}=100 \%$ & N/A & $\begin{array}{l}\text { OS (median) } \mathrm{PCl}=19.0 \mathrm{~m} \\
\text { Control }=15.4 \mathrm{~m}\end{array}$ & $\begin{array}{l}\text { The authors strongly believe that } \\
\mathrm{PCl} \text { should remain a standard of } \\
\text { care for patients with SCLC, after } \\
\text { response to initial treatment }\end{array}$ \\
\hline Liu et al. & 2019 & China & No. of patients $=385$ & $\begin{array}{l}\mathrm{PCl}=41 \% \\
\mathrm{CRT}=100 \%\end{array}$ & N/A & $\begin{array}{l}\text { OS }(\text { median })=57 \mathrm{~m} ; \text { OS }(2 \mathrm{yrs}) \\
=72.3 \% ; \text { OS }(3 \mathrm{yrs})=56.6 \% \\
\text { OS }(5 \mathrm{yrs})=47.1 \%\end{array}$ & $\begin{array}{l}\mathrm{PCI} \text { was associated with a } \\
\text { significant survival benefit for } \\
\text { LS-SCLC patients who had } \\
\text { CR to chemoradiotherapy, and } \\
\text { prolonged the time to BM, and } \\
\text { reduced the cumulative incidence } \\
\text { of BM }\end{array}$ \\
\hline Cabrero et al. & 2019 & Not available & $\begin{array}{l}\text { No. of patients }=98 \\
\text { Stage of disease }=40 \% \text { [LS] } \\
60 \%[E S]\end{array}$ & $\begin{array}{l}\mathrm{PCl}=37.5 \% \\
\mathrm{RT}=34.7 \%\end{array}$ & N/A & $\begin{array}{l}\text { No significant difference in } \\
\text { survival between the group } \\
\text { treated with RT }\end{array}$ & $\begin{array}{l}\text { We didn't find any difference } \\
\text { with } \mathrm{PCl} \text { or } \mathrm{Cl} \text { in overall survival } \\
\text { and } \mathrm{BR} \text {. A high proportion of the } \\
\text { patients in both groups (with/ } \\
\text { without } \mathrm{BM} \text { at diagnosis) didn't } \\
\text { receive radiotherapy, due to a very } \\
\text { poor clinical status }\end{array}$ \\
\hline
\end{tabular}

Table S2 (continued) 
Table S2 (continued)

\begin{tabular}{|c|c|c|c|c|c|c|c|}
\hline Author & Year & Country & Patient characteristics & Treatment received & Regimen & Outcomes & Conclusion \\
\hline Chung et al. & 2019 & Not available & $\begin{array}{l}\text { No. of patients }=190 \\
\text { Stage of disease }=100 \% \\
{[E S]}\end{array}$ & $\mathrm{PCl}=27.9 \%$ & N/A & $\begin{array}{l}\mathrm{OS}(1 \mathrm{yr}) \mathrm{PCl}=45 \% ; \mathrm{No}-\mathrm{PCl}= \\
50 \% ; \mathrm{BMFS}(1 \mathrm{yr}) \mathrm{PCl}=86.9 \% ; \\
\mathrm{No}-\mathrm{PCl}=52.5 \%, \mathrm{BMFS}(2 \mathrm{yr}) \\
\mathrm{PCl}=49.8 \% ; \mathrm{No}-\mathrm{PCl}=12.7 \%\end{array}$ & $\begin{array}{l}\text { Four prognostic factors are asso- } \\
\text { ciated with a high risk of symp- } \\
\text { tomatic brain metastasis in ED- } \\
\text { SCLC: presence of extrathoracic } \\
\text { metastases, FDG-PET uptake in } \\
\text { BM or spleen, PD after chemo- } \\
\text { therapy, and high Hb level }\end{array}$ \\
\hline \multicolumn{8}{|c|}{ Maintenance Chemotherapy } \\
\hline Yan et al. & 2018 & China & No. of patients $=25$ & Maintenance CT & Apatanib & $\begin{array}{l}\text { OS }(\text { median })=17 \mathrm{mo} \\
\text { PFS }(\text { median })=8.3 \mathrm{mo}\end{array}$ & $\begin{array}{l}\text { Maintenance apatinib was safe } \\
\text { and achieved encouraging PFS } \\
\text { and OS in extensive-stage SCLC. }\end{array}$ \\
\hline
\end{tabular}

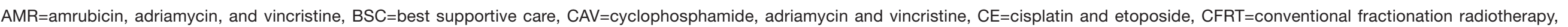

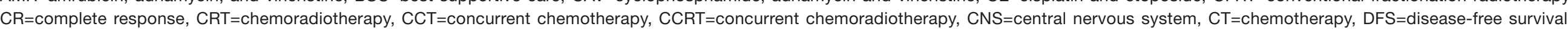

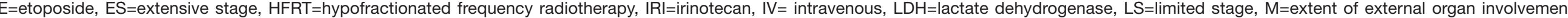

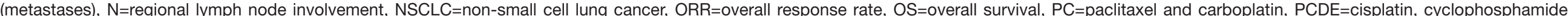

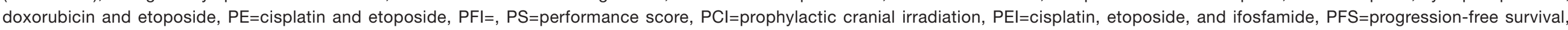
$\mathrm{RDT}=$ radiotherapy, SCLC=small cell lung cancer, $\mathrm{SCRT}=$ sequential chemoradiotherapy, $\mathrm{TRT}$ =thoracic radiotherapy, $\mathrm{T}=$ characteristics of the primary tumour 